\title{
Pollution Prevention Successes Database (P2SDb) User Guide
}

\author{
RECEIVED \\ NOV - 31995 \\ OSTI
}

\section{United States}

Department of Energy

Richland, Washington

Approved for Public Release 
LEGAL DISCLAIMER

This report was prepared as an account of work sponsored by an agency of the United States Government. Neither the United States Government nor any agency thereof, nor any of their employees, nor any of their contractors, subcontractors or their employees, makes any warranty, express or implied, or assumes any legal liability or responsibility for the accuracy, completeness, or any third party's use or the results of such use of any information, apparatus, product, of process disclosed, or represents that its use would not infringe privately owned righis. Reference herein to any specific commercial product, process, or service by trade name, trademark, manufacturer, or otherwise, does not necessarily constitute or imply its endorsement, recommendation, or favoring by the United States Government or any agency thereof of its contractors or subcontraciors. The views and opinions of authors expressed herein do not necessarily state or reflect those of the United States Government or any agency thereof.

This report has been reproduced from the best available copy. Available in paper copy and microfiche.

Available to the U.S. Department of Energy and its contractors from

Office of Scientific and Technical Information

P.0. $80 \times 62$

Oak Ridge, TN 37831

(615) $576-8401$

Available to the public from the U.S. Department of Commerce National Technical Information Service

5285 Port Royal Road

Springfield, VA 22161

(703) $487-4650$

Printed in the United States of America

DISCLM-1.CHP $(1.91)$ 


\section{DISCLAIMER}

Portions of this document may be illegible in electronic image products. Images are produced from the best available original document. 


\section{Pollution Prevention Successes Database (P2SDb) User Guide}

Westinghouse Hanford Company and ICF Kaiser Hantord Company

Date Published

July 1995

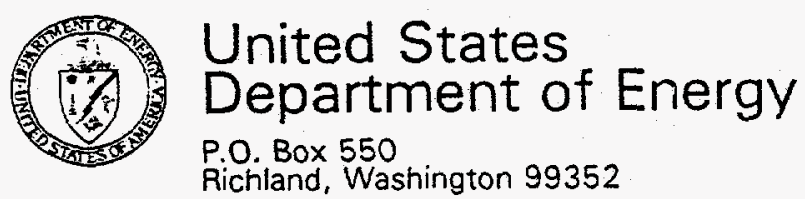

R.O. Box 550 Washington 99352 


\section{POLLUTION PREVENTION SUCCESSES DATABASE [P2SDb]}

\section{USER GUIDE}

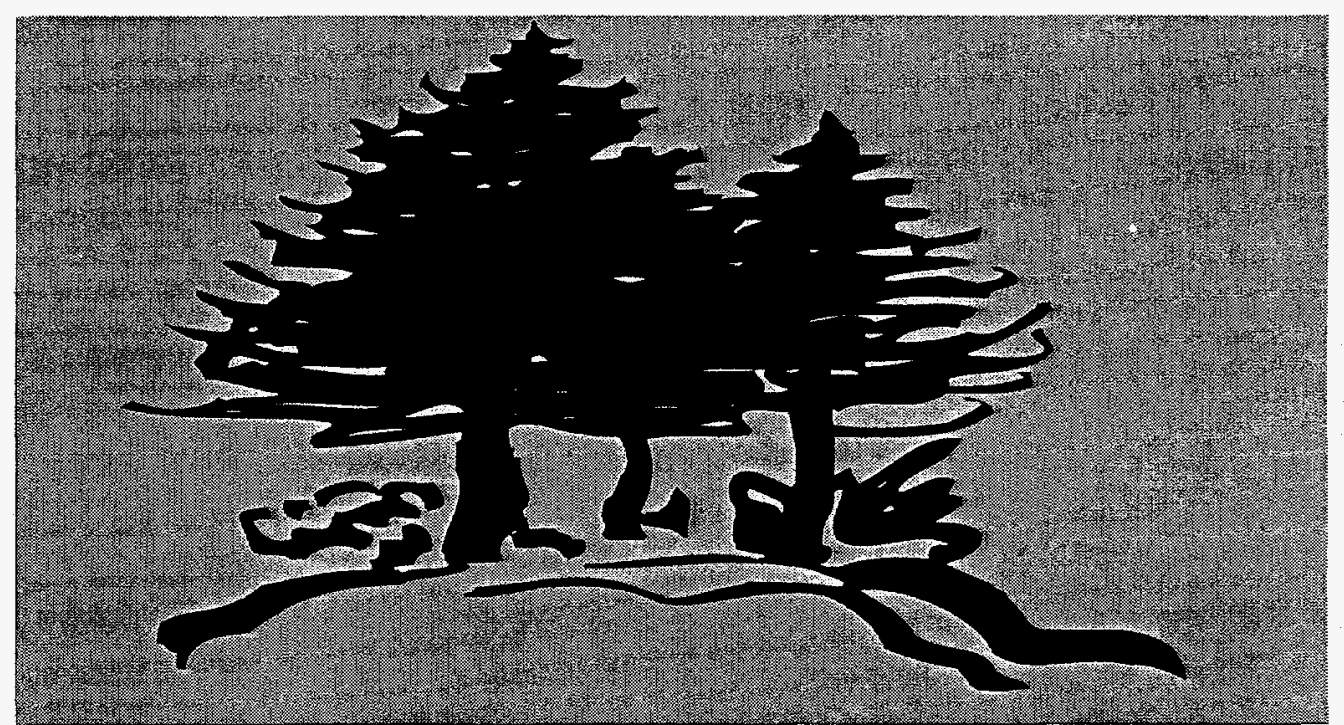

Developed For U.S. Department of Energy

Richland Operations

By

Westinghouse Hanford Company

$\&$

ICF Kaiser Hanford Company 
[This Page Left Intentionally Blank] 


\section{TABLE OF CONTENTS}

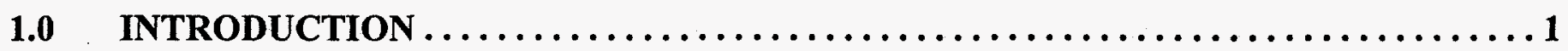

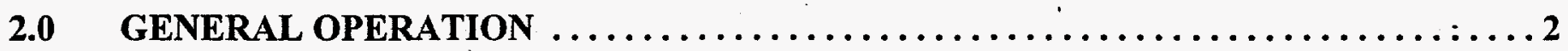

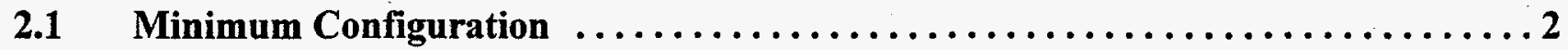

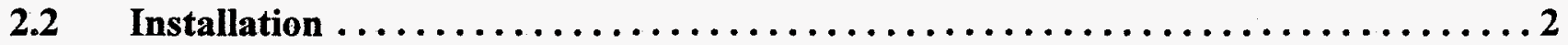

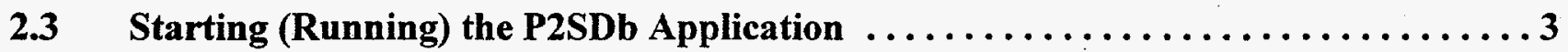

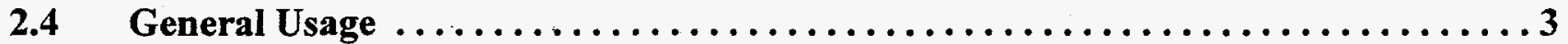

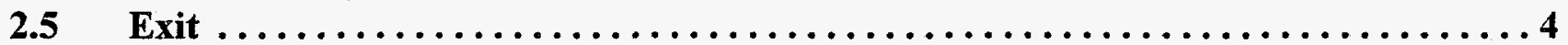

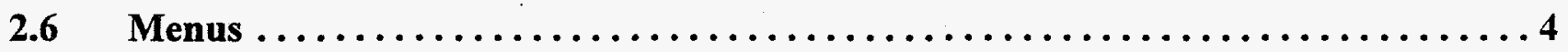

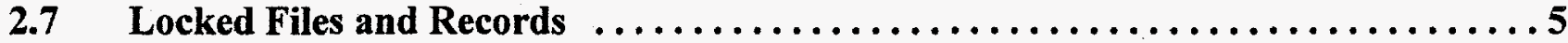

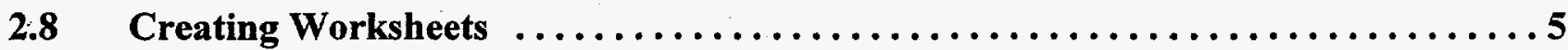

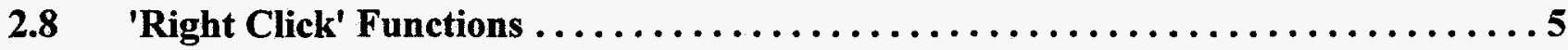

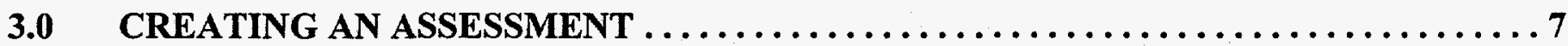

3.1 Defining A New Assessment (Worksheet 1 - Team \& Activity) $\ldots \ldots \ldots \ldots \ldots \ldots 7$

3.2 Entering Flow Information (Worksheet 2 - Activity Flow Diagram) ..........11

3.3 Entering One or More Opportunities (Worksheet 3 - Opportunity Worksheet) ... 15

3.4 Enter a New P2OA Worksheet 4 - Summary Worksheet ................ 19

4.0 ACCESS AND EDIT AN EXISTING ASSESSMENT $\ldots \ldots \ldots \ldots \ldots \ldots \ldots \ldots \ldots \ldots \ldots$

5.0 GENERATE ASSESSMENT REPORTS (How To Print) $\ldots \ldots \ldots \ldots \ldots \ldots \ldots \ldots \ldots$

6.0 COMMON QUESTIONS AND ANSWERS $\ldots \ldots \ldots \ldots \ldots \ldots \ldots \ldots \ldots \ldots \ldots \ldots \ldots \ldots \ldots \ldots$

7.0 REPORTING PROBLEMS AND REQUESTING ENHANCEMENTS $\ldots \ldots \ldots \ldots . \ldots 37$

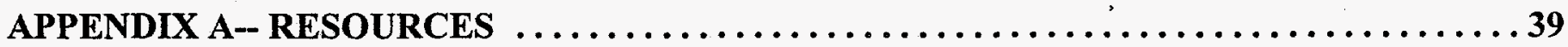

APPENDIX B-- WASTE MINIMIZATION CODES $\ldots \ldots \ldots \ldots \ldots \ldots \ldots \ldots \ldots \ldots \ldots \ldots$

APPENDIX C-- SOURCE CODE DESCRIPTIONS $\ldots \ldots \ldots \ldots \ldots \ldots \ldots \ldots \ldots \ldots \ldots \ldots, \ldots \ldots \ldots$

APPENDIX D-- FORM CODE DESCRIPTIONS $\ldots \ldots \ldots \ldots \ldots \ldots \ldots \ldots \ldots \ldots \ldots \ldots \ldots \ldots$

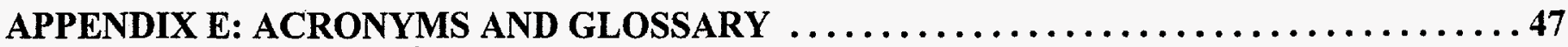


[This Page Left Intentionally Blank] 


\subsection{INTRODUCTION}

When Pollution Prevention Opportunity Assessments (P2OAs) were launched at the Hanford Site during the summer of 1994, the first comment received from those using them expressed the desire for a method to report assessments electronically. As a temporary measure, macros were developed for use on word processing systems, but a more formal database was obviously needed. Additionally, increased DOE and Washington state reporting requirements for pollution prevention suggested that a database system would streamline the reporting process.

The need for a system to track P2OAs was also identified by DOE-RL, and funding was received through DOE-HQ. EM-344. Meetings held in the summer of 1994 determined the criteria and functions that were most important to the end users of the system:

* Capable of handling all pollution prevention successes, not just from P2OAs

* User friendly

* Real time (on HLAN)

* On-line help feature

* Windows-driven icons

* Math included to do conversions and return on investment, etc.

* Usable by a 386

* Capable of printing out P2OA worksheets

* Error/integrity checking at the time of data entry

* Flexible to meet long-term needs

* Able to show successes implemented for reporting

* Flexible reports

* Output files compatible with SWITS and other Hanford systems

* Able to export data to spreadsheet (such as Excel)

* Capable of showing P2 accomplishments and what people are doing

* Capable of information exchange

The Pollution Prevention Group of Westinghouse Hanford Company (WHC) contracted with the Data Automation Engineering department from ICF Kaiser Hanford Company (ICFKH) to develop this system. The scope was to develop a database that will track P2OAs conducted by the facilities and contractors at the Hanford Site. It will also track pollution prevention accomplishments that are not the result of P2OAs and document a portion of the Process Waste Assessments conducted in the past.

To accommodate the above criteria, yet complete the system in a timely manner, the Pollution Prevention Successes Database (P2SDb) is being implemented in three phases. The first phase will automate the worksheets to provide both input and output of the data associated with the worksheets. The second phase will automate standard summary reports and ad hoc reports. The third phase will provide automated searching of the database to facilitate the sharing of pollution prevention experiences among various users. This User's Guide addresses only the Phase 1 system. 


\subsection{GENERAL OPERATION}

\subsection{Minimum Configuration}

The P2SDb system was designed to operate on Hanford site standard moderate to high end IBM compatible personal computers. Since it is a multi-contractor, multi-user system, it requires attachment to the Hanford Local Area Network (HLAN.) Beeause of the complexity of the system and the requirements for user friendly interface and high quality print, the $\mathrm{P} 2 \mathrm{SDb}$ requires operation with Microsoft Windows version 3.11 (Windows for Workgroups) and the new ESOE standard developed by Boeing Computer Services Richland. The following provides the minimum configuration that will provide satisfactory operational results.

- IBM compatible with a 386DX processor operating at $25 \mathrm{MHZ}$ (works best with 486 processor)

- $\quad$ VGA video/color monitor

- 8 Mbytes main system memory

- $\quad 30$ Mbytes of available disk space on your C: hard disk drive

- MS-DOS version 6.22, Windows for Workgroups

- Hanford site standard ESOE package, HLAN connection.

Operation with lower performance systems may be possible, but will be quite slow.

\section{$2.2^{\circ}$ Installation}

Installation of the P2SDb system will fail without the standard ESOE package provided by to the site by Boeing Computer Services Richland. Please contact them on 376-1234, or via cc:mail at ${ }^{*} \mathrm{CTS}$ to have your computer configured with ESOE.

The $\mathrm{P} 2 \mathrm{SDb}$ system is normally installed by the user, and is self configuring. Begin installation from the Microsoft Windows "Program Manager" group. Program Manager is sometimes labeled "Windows" in some installations.

Choose File, then Run (File/Run) from the Program Manager menu bar. Enter

\section{IIP2SDbInstalliSetup.exe}

in the box titled Command Line. Click OK or press Enter. An installer dialog box will appear. You may choose to continue or cancel the installation.

You will be given a choice between "local" and "network" installation. Local installation loads all application files except multi-user data files onto your local C: hard disk. It requires about 30 Mbytes of free disk space. This option provides optimum performance as access to files on your hard disk is much more rapid than across the HLAN. It is the preferred installation choice.

Network installation is available for those that do not have sufficient free disk space on their C: hard disk drives. It installs only the application startup files onto your local hard disk. Each time you start P2SDb, 
it retrieves the remaining application files from a network fileserver. This will not provide optimum performance as access to files from file servers is much slower. If you have no other choice, choose Network installation.

In performing its function, the Installer program will create a new Windows group titled Pollution Prevention. This group will have three icons. The P2SDb icon is used to start the application. The Installer icon is used to install new releases of the application, or to change the configuration (e.g., from Network to Local.) A third icon marked Read Me provides late breaking information that could not be included in the guide. It is recommended that you read the Read Me each time you use the installer.

You may re-install the application at any time. Assuming that your Installer icon is intact, you do not need to use the Program Manager File/Run menu and enter the installation string. Simply select (double mouse click) on the Installer icon.

If a new release of the $\mathrm{P} 2 \mathrm{SDb}$ is made available, you will be notified automatically when attempting to start (run) the application. You will not be allowed to operate the obsolete version, but be required to reinstall using the Installer icon.

\subsection{Starting (Running) the P2SDb Application}

The P2SDb application is started (launched) just as any other Windows application is. Open the group window where the P2SDb icon is located (default is the Pollution Prevention group.) Double mouse click on the icon.

Users will have accounts predefined by the P2SDb system administrator. When the logon screen appears, type your identification, which is typically your Hanford ID number. Then press 'tab' or 'enter' or use the mouse to select the password field. Enter the assigned password. Obtain your ID and password from the P2SDb system administrator. Your password will be echoed to the screen as asterisks $\left(^{*}\right)$. Press 'enter.' If the system does not recognize you, try reentering your password. If repeated attempts fail, contact your system administrator to verify your account. Upon successful logon you will see a box with the message to stand by while the system is loaded. Please be patient as the system preloads much of the software that is required so further operation performance is enhanced. You can observe the progress of the startup on the status line in the lower left corner. Loading is complete when the P2SDb main screen and menu appear (a large green tree graphic.)

\subsection{General Usage}

The P2SDb uses standard Windows graphical user interface conventions as much as practical. Items are selected and buttons (icons) pushed using a mouse or other pointing device to hover a screen pointer over the object, then clicking the left mouse button. Tabs to move from object to object and "Enter" key to select may also be used in most instances. You generally must select an input box before entering information into it. Many of the fields or objects display only a summary of information. The user may "inspect" the object, or bring up the detail, by using the right mouse click key (after selecting the object.) More information on right click is provided below. 
The menu bars (described below) enable you to move from one worksheet to another.

Messages will appear in the lower left corner of the form. Be alert for messages that provide helpful information.

The system has two modes--view mode and edit mode. Any user that logs on to the system may view all worksheet data and most lookup table information (user access control cannot be viewed). Authorization to edit must be set for any specific user by the system administrator.

Each system user can be authorized to enter new or modify worksheets for specific facilities. The system administrator will create a list of authorized facilities for each user. A user will see the list of facilities assigned to him or her when a new worksheet is created. Any system user may 'view' worksheets for all facilities.

The system starts in view mode. An authorized user can press F9 (enter edit mode) while in any worksheet, or by choosing Edit from the appropriate menu bar sub-menu. If the current worksheet represents a facility that is not authorized for data entry by the user, edit mode will be denied.

Fields that may be edited (while in edit mode) will be colored light blue. Note that the colors provided are influenced by the video board, driver, monitor and Windows color settings. Non-editable fields will be visibly darker.

Always select a field before using a "right click" feature (described below). Although it is possible to right click on a field without first selecting it, the result is not always consistent and it is better to select the field first by left clicking on it or to use the keyboard to navigate to the field.

Be patient. The system is multi-user and requires network transfer of data when responding to your commands. Traffic on the network and the number of concurrent users can create delays.

\subsection{Exit}

You may exit the P2SDb application from any worksheet or the main menu. Select the menu bar'exit' item. You will be prompted to verify your intent to exit the P2 system. Open tables will be closed and data will be saved.

\subsection{Menus}

Each worksheet and the main menu form have associated menu bars - the row of options listed across the top of the form. Any of these menu items may be selected - most will yield a vertical list of menu items. Selection of one of these items will generally yield access to a worksheet, a dialog box, or another list of menu items. 


\subsection{Locked Files and Records}

The Paradox database engine supports multiple users by locking records while data is being entered. These locks prevent one from writing over another's data. Be aware of these locking mechanisms. To be courteous to others, avoid having the system in Edit mode when you need only to browse. If you are locked out temporarily (message appears in lower left corner message line,) then Paradox is updating a file with another user's data.

\subsection{Creating Worksheets}

'Creating a worksheet,' in the context of P2 users, means to create a new set of information that fills a worksheet display. These worksheet instances are generally identified by the facility, date, and perhaps some facility details. Every worksheet instance will have a unique identifier created by the system.

To create a new worksheet instance:

- Use the Main Menu 'Worksheets' item and select the desired worksheet,

- $\quad$ Use the F9 key or 'Edit' menu item for the worksheet to enter edit mode (all editable fields will become light blue),

- $\quad$ Pull down the menu bar item that represents the worksheet's highest level of division, e.g., 'Activity' for the P20A worksheets. Select the 'New" menu item. The system will prompt you to select a facility from the list of facilities you are authorized to edit.

- $\quad$ Enter data in the light blue fields.

- Worksheets typically have embedded tables of information. Data may be entered in these tables either directly in the worksheets or in dialog boxes. Some tables will support scrolling to an empty record and entering data.

\section{$2.8 \quad$ 'Right Click' Functions}

Many worksheet fields have detail dialog boxes or auxiliary features that will enhance data entry. These enhancements are intended to improve data entry accuracy and efficiency. To access the auxiliary feature, click the right mouse button on the selected field. If no auxiliary feature exists for the field, there will be no change. The descriptions that follow assume the worksheet is in edit mode (so that changes are accepted). In view mode, these features may still be used but only for viewing options - not entering them. The types of enhancements are:

- $\quad$ Lookup Tables. Upon right click, a dialog box will appear with a field that may be "pulled down." Any entry in the list may be selected. All entries listed will be valid for the field. An "OK" button on the dialogue is used to conclude the selection. 
Memo Entry. There are many worksheet fields that will support unlimited text. Typically, the worksheet has little space available for much text. A right click on memo fields will bring up a dialog box with (1) more space and (2) support for text formatting (e.g., line feeds, tabs).

Units Conversion. Numeric data fields that deal with quantities will typically support a right click to the Units Conversion dialog. This is the same Units Conversion available via the Utilities menu item. The nice feature here is that the value currently in the numeric field will be automatically placed in the 'input' field of the Units Conversion dialog. If "OK" is used to return to the work sheet, the results of the conversion are automatically placed into the field. The user is responsible for updating any units specification field that may be associated with the number.

Today's Date. A date field may provide a right click option to automatically enter the current date. Upon right click, you are prompted to accept or reject the auto entry. 


\subsection{CREATING AN ASSESSMENT}

Creating the five worksheets for a consistent assessment is a primary and most used function of the $\mathrm{P} 2 \mathrm{SDb}$ application. There are five sections herein corresponding to each of the five P2OA Worksheets.

- Worksheet 1 - Team \& Activity

- Worksheet 2 - Activity Flow Diagram

- Worksheet 3 - Pollution Prevention Opportunity

- Worksheet 4 - Pollution Prevention Opportunity Summary

- Worksheet 5 - Final Summary

\subsection{Defining A New Assessment (Worksheet 1 - Team \& Activity)}

Worksheet 1 is where initial assessment activity and team information is provided. When Worksheet 1 is first chosen, you will see the information for the first existing assessment in the database. This may or may not for a facility you are responsible for. Figure 3.1 shows the main view and edit screen for the worksheet. Table 3.1 provides step by step instructions for creating a new assessment using a blank copy of Worksheet 1. See Appendix B for definitions of each of the entry fields used in this worksheet.

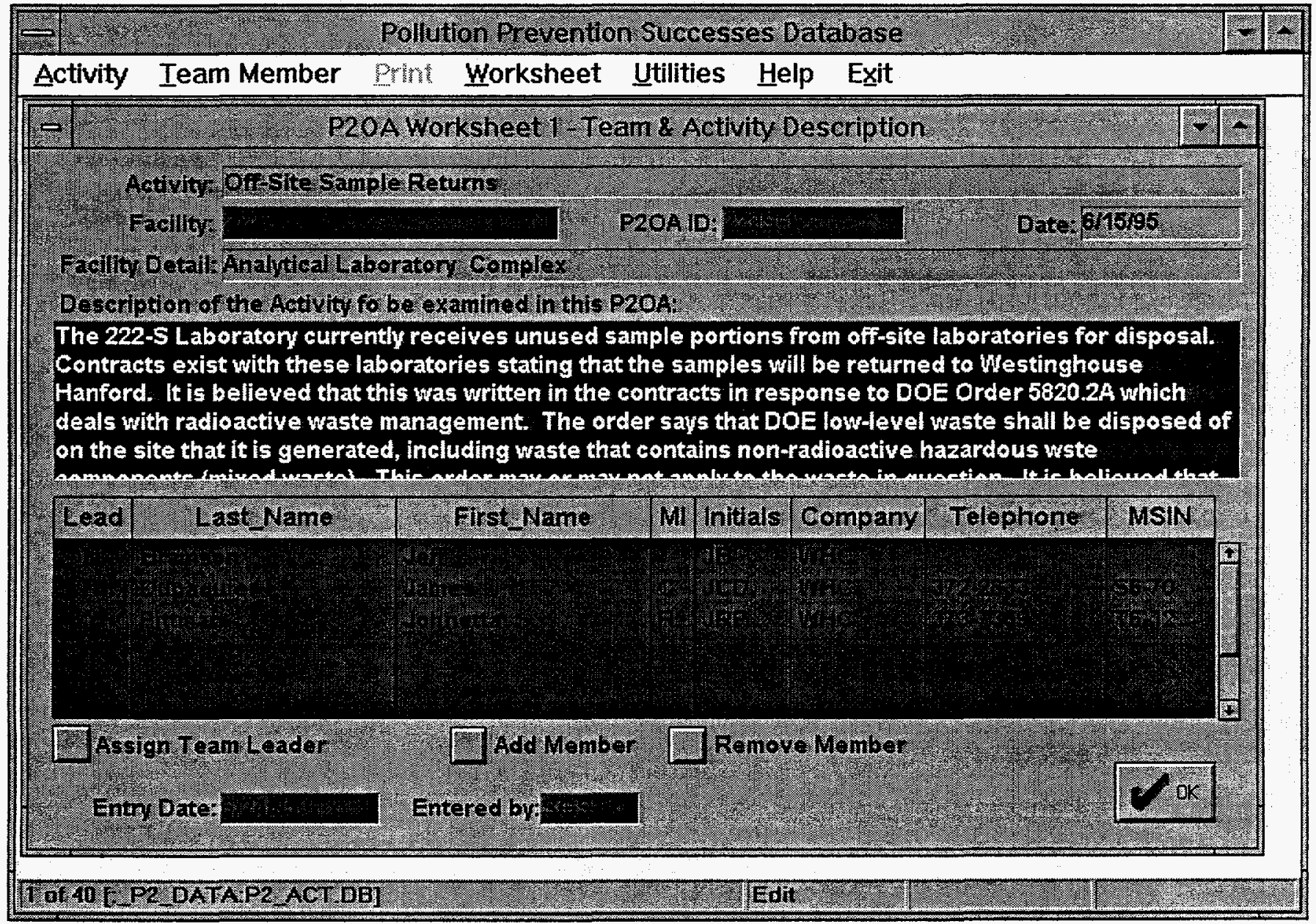

Figure 3.1 
Table 3.1

\begin{tabular}{|c|c|c|}
\hline \multicolumn{3}{|r|}{ Worksheet 1 - Team \& Activity } \\
\hline & General Steps & Detail or Comment \\
\hline 1. & Start P2SDb & Click the left mouse button twice (rapidly) while pointing to the P2SDb icon. \\
\hline 2. & Log on P2 system. & $\begin{array}{l}\text { Type your Hanford ID (or payroll number) and press Enter. Type your password and } \\
\text { select OK. }\end{array}$ \\
\hline 3. & $\begin{array}{l}\text { Select } \\
\text { Worksheets/P2OA } \\
\text { Worksheets. }\end{array}$ & $\begin{array}{l}\text { Select (click the left mouse button once while pointing to) "Worksheets" on P2 } \\
\text { Main's horizontal menu bar. } \\
\text { Select "P2OA Worksheets" on the pulldown menu beneath "Worksheets." After a } \\
\text { moment, you should see a form similar to Figure } 3.1 \text { appear on your screen. }\end{array}$ \\
\hline 4. & Select Activity/New. & $\begin{array}{l}\text { Select "Activity" on P2OA Worksheet 1's menu bar. } \\
\text { Select "New" on the pulldown menu beneath "Activity." A "Facility Selection for } \\
\text { New Worksheet" dialog box should appear. }\end{array}$ \\
\hline 5. & Enter Facility. & $\begin{array}{l}\text { Facility is the facility or location where the activity occurs. } \\
\text { In the "Facility Selection for New Worksheet" dialog box, select the drop-down } \\
\text { arrow. Select the facility from the valid facilities authorized for you. Note: contact } \\
\text { system administrator to add or modify your authorized facility list. } \\
\text { Select OK. You will return to a new Worksheet } 1 \text { with Facility entered and a new } \\
\text { P2OA ID assigned. You cannot change this information, but may select } \\
\text { Activity/Delete from the main menu to start over if you have the wrong facility. }\end{array}$ \\
\hline 6. & Enter Activity. & $\begin{array}{l}\text { Activity is the waste generating activity for the P2OA. } \\
\text { Select the Activity entry box to type in this field. } \\
\text { Note: to move to (select) each entry field, you may use the mouse or 'tab' key. }\end{array}$ \\
\hline 7. & Enter date. & $\begin{array}{l}\text { Date is the initiation date of this P2OA. You may accept (leave as is) or overwrite the } \\
\text { date displayed. }\end{array}$ \\
\hline 8. & Enter facility detail. & Facility Detail is the specific information on activity location. \\
\hline 9. & $\begin{array}{l}\text { Enter Description of the } \\
\text { Activity. }\end{array}$ & $\begin{array}{l}\text { Expanded freeform text on the waste generating activity. } \\
\text { Select the Description of the Activity entry box to type in this field. } \\
\text { Note: Clicking the right hand mouse button once while pointing to the description } \\
\text { entry area, an expanded editing box will appear with more word processing type } \\
\text { features available (paragraphs, indents, delete, backspace, etc.) }\end{array}$ \\
\hline
\end{tabular}




\begin{tabular}{|c|c|c|}
\hline \multicolumn{3}{|r|}{ Worksheet 1 - Team \& Activity } \\
\hline & General Steps & Detail or Comment \\
\hline 10. & Add Team Members. & $\begin{array}{l}\text { You cannot add team members directly in table box shown (spreadsheet type area.) } \\
\text { Press "Add Member" button with mouse. A "Team Member Selection" dialog box } \\
\text { will appear. You must be in Edit mode, authorized to edit or add new assessments and } \\
\text { be authorized to make assessments for the facility. The mode indicator is located on } \\
\text { the bottom line. } \\
\text { Use the vertical (up and down) scroll bars to view the current list of valid team } \\
\text { members. Select (highlight) the appropriate member, then select "OK". The selected } \\
\text { member will be added to the table box on Worksheet } 1 \text {. If a team member is not } \\
\text { currently in the valid team member list, see step } 11 \text {. } \\
\text { Repeat this step to add each team member. }\end{array}$ \\
\hline 11. & $\begin{array}{l}\text { New Team Members } \\
\text { (New User) }\end{array}$ & $\begin{array}{l}\text { If in step } 10 \text { you did not find the appropriate member in the valid team member list, } \\
\text { you need to add the individual to the User list. } \\
\text { From Worksheet } 1 \text {, select "Add Member" box. A "Team Member Selection" dialog } \\
\text { box should appear. } \\
\text { Select "New User." P2SDb should display the "P2 System User Profile Maintenance" } \\
\text { dialog box. Select (highlight) any existing user name. } \\
\text { Press "Insert" key. A new blank row should appear in the User Profile list. } \\
\text { Enter User/Member information. Please be complete. If you do not know the } \\
\text { member's Hanford ID, any unique combination of numbers or letters will work. } \\
\text { Select OK. This should return you to the "Team Member Selection" dialog box of } \\
\text { Worksheet } 1 \text {, and the new member should be available in the scrolling window. } \\
\text { Continue on with the remaining steps in } 10 . \\
\text { Note: a key violation will occur if the ID is used by other user (message will appear in } \\
\text { lower left corner.) If this occurs, try another User ID value. }\end{array}$ \\
\hline 12. & $\begin{array}{l}\text { Assign Team Leader. } \\
\text { Remove Member }\end{array}$ & $\begin{array}{l}\text { Select (highlight) the appropriate member. } \\
\text { Press indicated button with mouse to initiate action. }\end{array}$ \\
\hline
\end{tabular}




\begin{tabular}{|l|l|}
\hline \multicolumn{2}{|c|}{ Worksheet 1 - Team \& Activity } \\
\hline General Steps & \multicolumn{1}{|c|}{ Detail or Comment } \\
\hline 13. Continue, Print or Exit. & $\begin{array}{l}\text { The initial assessment information for Worksheet 1 should be complete. You may } \\
\text { continue entry of worksheets } 2 \text { or } 3 \text { associated with this assessment, print a copy of } \\
\text { worksheet 1 or exit the P2SDb application. } \\
\text { To exit the application, select OK button on the worksheet (records the entered } \\
\text { information and returns to "view" mode,) Select "Exit" from the main menu bar. } \\
\text { To print the current worksheet, select "Print" from the main menu bar, then "Print } \\
\text { Worksheet" from the pulldown. You may choose to preview the report on the screen } \\
\text { first, or immediately print. See Section 5, "Printing Worksheets" for more } \\
\text { information. Note: you must be in "View" mode to Print. If in "Edit" press F9 or } \\
\text { select Opportunity/View from the menu bar. } \\
\text { To continue entry of associated worksheets, select "Worksheet" from the main menu } \\
\text { bar. Select the worksheet you wish to work with next from the menu pulldown list. } \\
\text { To create a new Team \& Activity Worksheet 1, select "OK" button, then repeat the } \\
\text { steps in this table. }\end{array}$ \\
\hline
\end{tabular}




\subsection{Entering Flow Information (Worksheet 2 - Activity Flow Diagram)}

Flow information for a particular P2OA is entered in Worksheet 2 - Activity Flow Diagram. Worksheet 2 must be associated with a previously entered Worksheet 1 - Team \& Activity. It cannot be initiated first. Activity information from the associated Worksheet 1 is automatically placed on the form for you. You cannot edit the Activity, Facility, P2OA ID or Facility Detail fields on Worksheet 2. If they are in error, they must be changed on Worksheet 1 . There is only one Flow Information Worksheet available for each activity.

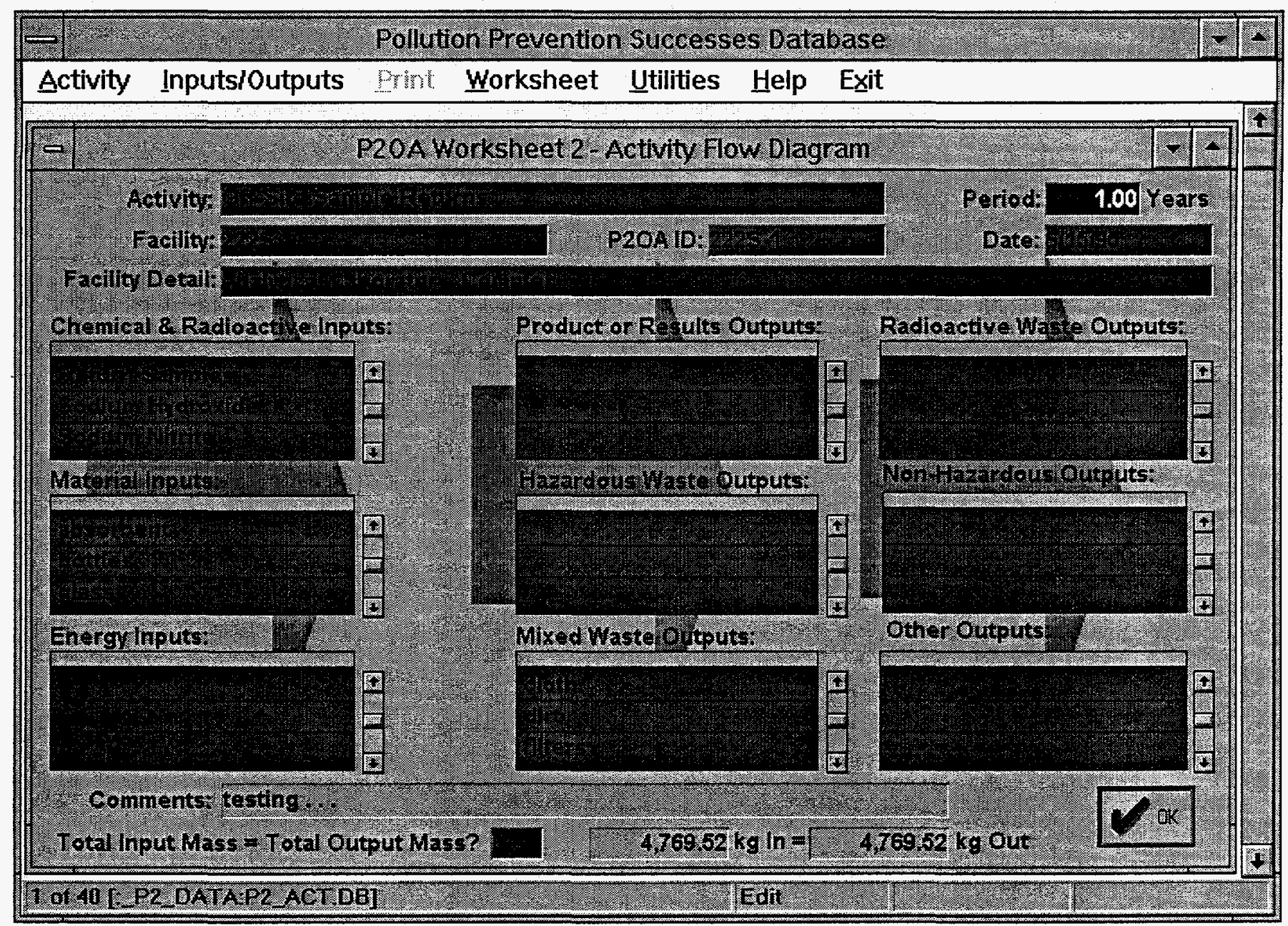

Figure 3.2 
Table 3.2

\begin{tabular}{|c|c|c|}
\hline \multicolumn{3}{|r|}{ Worksheet 2 - Activity Flow Diagram } \\
\hline & General Steps & Detail or Comment \\
\hline 1. & $\begin{array}{l}\text { Start application, select } \\
\text { activity. }\end{array}$ & If not continuing from Worksheet 1 , complete steps 1 through 3 in table 3.1 above. \\
\hline $2 a$. & $\begin{array}{l}\text { Select Activity/List } \\
\text { Activities. }\end{array}$ & $\begin{array}{l}\text { Note: alternative step } 2 \mathrm{~b} \text { may be faster if you know the P2OA ID you want. } \\
\text { Select (hover the mouse pointer over the object and click the left mouse button once) } \\
\text { "Activity" on the main menu bar. } \\
\text { Select "List Activities" from the pulldown menu list. An "Activities" dialog box } \\
\text { appears. } \\
\text { Select the drop-down arrow, then select the appropriate activity from the list. Use the } \\
\text { vertical scroll bar to rapidly move between activities. } \\
\text { Press "OK" button to return the selection to Worksheet } 1 \text {. }\end{array}$ \\
\hline $2 \mathrm{~b}$. & $\begin{array}{l}\text { (Alternative) } \\
\text { Select Activity/Locate. }\end{array}$ & $\begin{array}{l}\text { Select "Activity" on the main menu bar. } \\
\text { Select "Locate" from the pulldown menu list. A "Locate Value" dialog box appears. } \\
\text { Enter a value to search for. (Use .. for wildcards, e.g., " } 222 . . \text { " will find the first record } \\
\text { starting with " } 222 \text { " . } \\
\text { Select the field to search on. Hint: "Facility_ID" is the Facility. This may be a quick } \\
\text { way to find activities associated with a given facility. } \\
\text { Press "OK" button. The first instance of the associated search value will be located. } \\
\text { You may move up or down through the "stack" of existing P2OA's using the F11 and } \\
\text { F12 function keys if your keyboard supports these or use Activity/Previous } \\
\text { Activity/Next from the main menu. }\end{array}$ \\
\hline 3. & $\begin{array}{l}\text { Select Worksheet/Go } \\
\text { To Flow Worksheet }\end{array}$ & $\begin{array}{l}\text { Select "Worksheet" on P2OA Worksheet l's menu bar. } \\
\text { Select "Go To Flow Worksheet" on the pulldown menu. In a moment, Worksheet } 2 \\
\text { should appear. }\end{array}$ \\
\hline 4. & $\begin{array}{l}\text { Check for proper } \mathrm{P} 2 \mathrm{O} \\
\text { Activity. }\end{array}$ & $\begin{array}{l}\text { You should now be on P2OA Worksheet } 2 \text { - Activity Flow Diagram. Ensure the } \\
\text { appropriate activity and facility is shown. Check the message line (bottom left corner) } \\
\text { for any messages. If the proper facility and activity does not show, select } \\
\text { "Worksheet/Go to Activities Worksheet" from the main menu bar and repeat steps } 2 \\
\text { and } 3 \text {. Alternatively, you may use similar menu selections under "Activity" in the } \\
\text { menu bar for Worksheet } 2 \text {. } \\
\text { Note: Activity, Facility, P2OA ID, Date and Facility Detail are obtained from } \\
\text { Worksheet } 1 \text {. You cannot change these fields from Worksheet } 2 \text {. }\end{array}$ \\
\hline
\end{tabular}




\begin{tabular}{|c|c|c|}
\hline \multicolumn{3}{|r|}{ Worksheet 2 - Activity Flow Diagram } \\
\hline & General Steps & Detail or Comment \\
\hline 5. & Check for "Edit" mode. & $\begin{array}{l}\text { If you were continuing from entry of Worksheet 1, "Edit" mode should have been } \\
\text { maintained. Check the mode indicator located on the bottom line. If "Edit" is not } \\
\text { showing, you are in "View" mode. Press F9 function key (alternatively, select } \\
\text { "Activity/Edit" from the menu bar) to enter "Edit" mode. Note: you must have } \\
\text { facility specific authorization to edit. Any form may be viewed. }\end{array}$ \\
\hline 6. & $\begin{array}{l}\text { Enter Chemical \& } \\
\text { Radioactive Inputs }\end{array}$ & $\begin{array}{l}\text { Chemical \& Radioactive Inputs are the regulated materials used by the activity. } \\
\text { Select Inputs/Outputs from the menu bar. } \\
\text { Select "Chemical Radioactive Inputs" from the pulldown list. Alternatively, you may } \\
\text { right-click the top highlighted bar of the associated list box. } \\
\text { A "Chemical \& Radioactive Inputs" dialog box should appear. Enter Component } \\
\text { Name, Waste Class designator, Quantity and Units. } \\
\text { Hints: Select (highlight) then right-click mouse on either Waste Class or Units block } \\
\text { to choose from the respective authorized lists (lookup table). A value other } \\
\text { than those available on these lists will be rejected (message will appear in } \\
\text { lower left corner.) Only system administrator can modify or add to these } \\
\text { authorized values. } \\
\text { There is no limit to the number of Components that can be entered. } \\
\text { However, they cannot have duplicate names. This is indicated by "Key } \\
\text { Violation" message appearing in the lower corner message line. Re-title to } \\
\text { be more uniquely descriptive. } \\
\text { Press "OK" button with mouse when all components are added. }\end{array}$ \\
\hline 7. & $\begin{array}{l}\text { Enter Other Inputs and } \\
\text { Outputs. }\end{array}$ & Repeat step 6 for the other inputs and outputs that apply. \\
\hline 8. & Enter Comments. & $\begin{array}{l}\text { Comments are caveats, references and/or other notations associated with this } \mathrm{P} 2 \mathrm{OA} \\
\text { Worksheet } 2 \text {. }\end{array}$ \\
\hline 9. & $\begin{array}{l}\text { Enter "Total Input } \\
\text { Mass= Total Output } \\
\text { Mass?" }\end{array}$ & $\begin{array}{l}\text { Answer the question "Does the Total Input Mass= Total Output Mass?" } \\
\text { Select the answer edit window. Type in Y or N for yes or no respectively. Note: this } \\
\text { question must be answered } Y \text { or N. Blank is not allowed. If you cannot leave this } \\
\text { worksheet, check to ensure you have entered a value. }\end{array}$ \\
\hline
\end{tabular}




\begin{tabular}{|c|c|c|}
\hline \multicolumn{3}{|r|}{ Worksheet 2 - Activity Flow Diagram } \\
\hline & General Steps & Detail or Comment \\
\hline & Continue, Print or Exit. & $\begin{array}{l}\text { The initial assessment information for Worksheet } 2 \text { should be complete. You may } \\
\text { continue entry of worksheet } 3 \text { associated with this assessment, print a copy of } \\
\text { worksheet } 2 \text { or exit the P2SDb application. } \\
\text { To exit the application, select OK button on the worksheet (records the entered } \\
\text { information and returns to "view" mode.) Select "Exit" from the main menu bar. } \\
\text { To print the current worksheet, select "Print" from the main menu bar, then "Print } \\
\text { Worksheet" from the pulldown. You may choose to preview the report on the screen } \\
\text { first, or immediately print. See Section 5, "Printing Worksheets" for more } \\
\text { information. Note: you must be in "View" mode to Print. If in "Edit" press F9 or } \\
\text { select Opportunity/View from the menu bar. } \\
\text { To continue entry of associated worksheets, select "Worksheet" from the main menu } \\
\text { bar. Select the worksheet you wish to work with next from the menu pulldown list. }\end{array}$ \\
\hline
\end{tabular}




\subsection{Entering One or More Opportunities (Worksheet 3 - Opportunity Worksheet)}

Information on opportunities for a particular P2OA is entered in Worksheet 3 - Pollution Prevention Opportunity Description. Worksheet 3 must be associated with a previously entered Worksheet 1 - Team $\&$ Activity. It cannot be initiated first. Activity information from the associated Worksheet 1 is automatically placed on the form for you. You cannot edit the Activity, Facility, P2OA ID or Facility Detail fields on Worksheet 3. If they are in error, they must be changed on Worksheet 1. Just as there are usually more than one opportunity identified with each P2O Activity, there may be more than one Opportunity Worksheet 3 for each Worksheet 1- Team \& Activity.



Figure 3.3 
Table 3.3

\begin{tabular}{|c|c|c|}
\hline \multicolumn{3}{|c|}{ Worksheet 3 - Pollution Prevention Opportunity Description } \\
\hline & General Steps & Detail or Comment \\
\hline 1. & $\begin{array}{l}\text { Start application, select } \\
\text { activity. }\end{array}$ & If not continuing from Worksheet 1 , complete steps 1 through 3 in table 3.1 above. \\
\hline $2 \mathrm{a}$. & $\begin{array}{l}\text { Select Activity/List } \\
\text { Activities. }\end{array}$ & $\begin{array}{l}\text { Note: alternative step } 2 \mathrm{~b} \text { may be faster if you know the P2OA ID you want. } \\
\text { Select (hover the mouse pointer over the object and click the left mouse button once) } \\
\text { "Activity" on the main menu bar. } \\
\text { Select "List Activities" from the pulldown menu list. An "Activities" dialog box } \\
\text { appears. } \\
\text { Select the drop-down arrow, then select the appropriate activity from the list. Use the } \\
\text { vertical scroll bar to rapidly move between activities. } \\
\text { Press "OK" button to return the selection to Worksheet } 1 \text {. }\end{array}$ \\
\hline $2 b$. & $\begin{array}{l}\text { (Alternative) } \\
\text { Select Activity/Locate. }\end{array}$ & $\begin{array}{l}\text { Select "Activity" on the main menu bar. } \\
\text { Select "Locate" from the pulldown menu list. A."Locate Value" dialog box appears. } \\
\text { Enter a value to search for. (Use .. for wildcards, e.g., " } 222 . . \text { " will find the first record } \\
\text { starting with" } 222 \text { ". } \\
\text { Select the field to search on. Hint: "Facility_ID" is the Facility. This may be a quick } \\
\text { way to find activities associated with a given facility. } \\
\text { Press "OK" button. The first instance of the associated search value will be located. } \\
\text { You may move up or down through the "stack" of existing P2OA's using the F11 and } \\
\text { F12 function keys if your keyboard supports these or use Activity/Previous } \\
\text { Activity/Next from the main menu. }\end{array}$ \\
\hline 3. & $\begin{array}{l}\text { Select Worksheet/Go } \\
\text { To Opportunity } \\
\text { Worksheet }\end{array}$ & $\begin{array}{l}\text { Select "Worksheet" on P2OA Worksheet l's menu bar. } \\
\text { Select "Go To Opportunity Worksheet" on the pulldown menu. In a moment, } \\
\text { Worksheet } 3 \text { should appear. }\end{array}$ \\
\hline 4. & $\begin{array}{l}\text { Check for proper } \mathrm{P} 2 \mathrm{O} \\
\text { Activity. }\end{array}$ & $\begin{array}{l}\text { You should now be on P2OA Worksheet } 3 \text { - Pollution Prevention Opportunity } \\
\text { Description. Ensure the appropriate activity and facility is shown. Check the message } \\
\text { line (bottom left corner) for any messages. If the proper facility and activity does not } \\
\text { show, select "Worksheet/Go to Activities Worksheet" from the main menu bar and } \\
\text { repeat steps } 2 \text { and } 3 \text {. Alternatively, you may use similar menu selections under } \\
\text { "Activity" in the menu bar for Worksheet } 3 \text {. } \\
\text { Note: Activity, Facility, P2OA ID, Date and Facility Detail are obtained from } \\
\text { Worksheet } 1 \text {. You cannot change these fields from Worksheet } 3 \text {. The P2O Number is } \\
\text { assigned automatically, and cannot be modified. }\end{array}$ \\
\hline
\end{tabular}




\begin{tabular}{|c|c|c|}
\hline \multicolumn{3}{|c|}{ Worksheet 3 - Pollution Prevention Opportunity Description } \\
\hline & General Steps & Detail or Comment \\
\hline 5. & Check for "Edit" mode. & $\begin{array}{l}\text { If you were continuing from entry of Worksheet 1, "Edit" mode should have been } \\
\text { maintained. Check the mode indicator located on the bottom line. If "Edit" is not } \\
\text { showing, you are in "View" mode. Press F9 function key (alternatively, select } \\
\text { "Activity/Edit" from the menu bar) to enter "Edit" mode. Note: you must have } \\
\text { facility specific authorization to edit. Any form may be viewed. }\end{array}$ \\
\hline 6. & Enter P2O Title. & $\begin{array}{l}\text { P2O Title is a brief description of the opportunity. } \\
\text { Select the "P2O Title" entry box to type in this field. }\end{array}$ \\
\hline 7. & Enter Current Practice. & $\begin{array}{l}\text { Current Practice is the current method of waste generation. } \\
\text { Select "Current Practice" entry box to type in this field. } \\
\text { Note: Clicking the right hand mouse button once while pointing to the Current } \\
\text { Practice entry area, an expanded editing box will appear with more word processing } \\
\text { type features available (paragraphs, indents, delete, backspace, etc.) }\end{array}$ \\
\hline 8. & $\begin{array}{l}\text { Enter Recommended } \\
\text { Action. }\end{array}$ & $\begin{array}{l}\text { Recommended Action is the proposed P2 opportunity alternative. } \\
\text { Select "Recommended Action" entry box to type in this field. } \\
\text { Mouse right-click for an expanded editing box. }\end{array}$ \\
\hline 9. & $\begin{array}{l}\text { Enter Calculation of } \\
\text { Waste Reduction and/or } \\
\text { Energy Savings. }\end{array}$ & $\begin{array}{l}\text { Calculation of Waste Reduction and/or Energy Savings is the method, calculations } \\
\text { and references for waste reduction. } \\
\text { Select "Calculation of Waste Reduction and/or Energy Savings" entry box to type in } \\
\text { this field. } \\
\text { Mouse right-click for an expanded editing box. }\end{array}$ \\
\hline 10. & Enter Waste Details. & $\begin{array}{l}\text { Press the "Waste Details" button to enter waste class reduction details. An } \\
\text { "Opportunity Waste Details" dialog box will appear. } \\
\text { Enter appropriate information for one or more waste classes in the table. } \\
\text { Hints: Select (highlight) then right-click mouse on either Waste Class or Units block } \\
\text { to choose from the respective authorized lists (lookup table). A value other } \\
\text { than those available on these lists will be rejected (message will appear in } \\
\text { lower left corner.) Only system administrator can modify or add to these } \\
\text { authorized values. } \\
\text { There is no limit to the number of waste classes that can be entered. } \\
\text { However, they cannot be listed more than once. This is indicated by "Key } \\
\text { Violation" message appearing in the lower corner message line. Hold down } \\
\text { the Ctrl key, then press the Delete key (Ctrl-Delete) to remove the duplicate } \\
\text { waste class entry. Combine entry for one type of waste class into a single } \\
\text { line entry. } \\
\text { Press "OK" button with mouse when all components are added. }\end{array}$ \\
\hline
\end{tabular}




\begin{tabular}{|c|c|c|}
\hline \multicolumn{3}{|c|}{ Worksheet 3 - Pollution Prevention Opportunity Description } \\
\hline & General Steps & Detail or Comment \\
\hline 11. & $\begin{array}{l}\text { Enter Total Annual } \\
\text { Savings Years. }\end{array}$ & $\begin{array}{l}\text { The Total Annual Savings will be calculated from the waste details. However, you } \\
\text { must enter the total years the Total Annual Savings will apply to. } \\
\text { Select "Yrs." entry field in the sentence "Total Annual Savings: \$ } \\
\text { to type in this field. } \\
\text { Note: Values in the Total Implementation Costs: fields are automatically calculated } \\
\text { from the waste details. }\end{array}$ \\
\hline 12. & Enter Comments. & $\begin{array}{l}\text { Comments are caveats, references and/or other notations associated with this } \mathrm{P} 2 \mathrm{OA} \\
\text { Worksheet } 3 \text {. }\end{array}$ \\
\hline 13. & $\begin{array}{l}\text { Entry Date and Entered } \\
\text { By fields. }\end{array}$ & $\begin{array}{l}\text { The "Entry Date" and "Entered By" are automatically filled in from the logon and } \\
\text { current date information. }\end{array}$ \\
\hline 14. & $\begin{array}{l}\text { Enter additional } \\
\text { opportunities. }\end{array}$ & $\begin{array}{l}\text { Additional opportunities associated with an activity are documented on separate } \\
\text { Worksheet 3's. } \\
\text { Select "Opportunity" on the menu bar. } \\
\text { Select "Opportunity New" on the pulldown list. A new worksheet should appear with } \\
\text { a new P2O No. Assigned. } \\
\text { Repeat steps } 4 \text { through } 13 \text { for each opportunity description. }\end{array}$ \\
\hline 15. & Continue, Print or Exit. & $\begin{array}{l}\text { The initial assessment information for Worksheet } 3 \text { should be complete. You may } \\
\text { continue entry of worksheet } 4 \text { associated with this assessment, print copies of all } \\
\text { worksheet } 3 \text { opportunity descriptions or exit the P2SDb application. } \\
\text { To exit the application, select OK button on the worksheet (records the entered } \\
\text { information and returns to "view" mode.) Select "Exit" from the main menu bar. } \\
\text { To print the current worksheet, select "Print" from the main menu bar, then "Print } \\
\text { Worksheet" from the pulldown. You may choose to preview the report on the screen } \\
\text { first, or immediately print. See Section 5, "Printing Worksheets" for more } \\
\text { information. Note: you must be in "View" mode to Print. If in "Edit" press F9 or } \\
\text { select Opportunity/View from the menu bar. } \\
\text { To continue entry of associated worksheets, select "Worksheet" from the main menu } \\
\text { bar. Select the worksheet you wish to work with next from the menu pulldown list. }\end{array}$ \\
\hline
\end{tabular}




\subsection{Enter a New P2OA Worksheet 4 - Summary Worksheet}

Summary information for a particular P2OA is entered in Worksheet 3 - Pollution Prevention Opportunity Summary. Worksheet 4 must be associated with a previously entered Worksheet 1 - Team \& Activity and Worksheet 2- Pollution Prevention Opportunity Description(s). It cannot be initiated first. Activity information from the associated Worksheet 1 is automatically placed on the form for you, as well as summary information from the associated opportunity worksheets. You cannot edit the Activity, Facility, P2OA ID or Facility Detail fields on Worksheet 4, or any of the opportunity information in the $\mathrm{P} 2 \mathrm{O}$ table. If they are in error, they must be changed on the respective Worksheet 1 or 3. There is only one Summary Worksheet available for each activity.

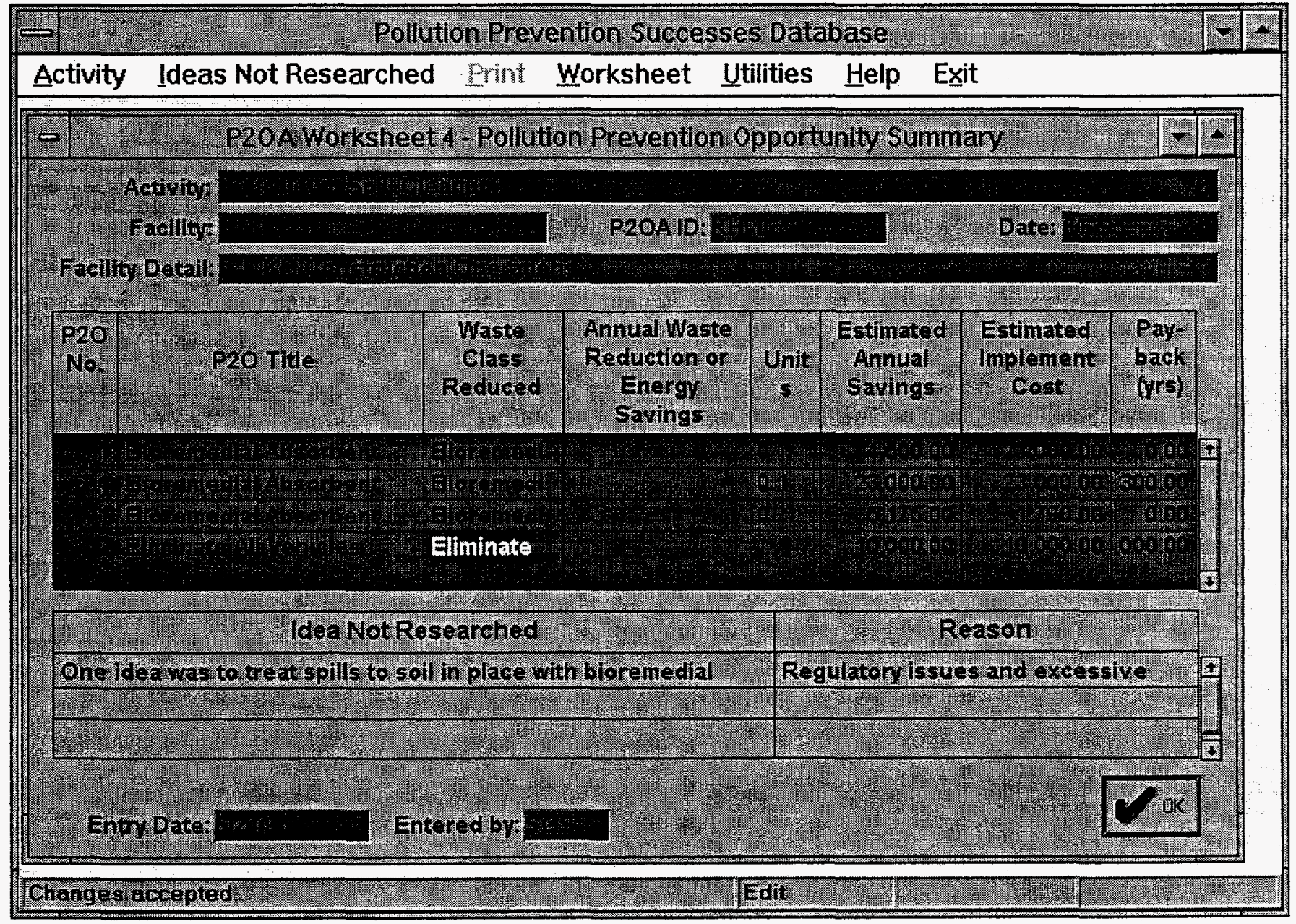

Figure 3.4 
Table 3.4

\begin{tabular}{|c|c|c|}
\hline \multicolumn{3}{|c|}{ Worksheet 4 - Pollution Prevention Opportunity Summary } \\
\hline & General Steps & Detail or Comment \\
\hline 1. & $\begin{array}{l}\text { Start application, select } \\
\text { activity. }\end{array}$ & If not continuing from Worksheet 1 , complete steps 1 through 3 in table 3.1 above. \\
\hline $2 a$. & $\begin{array}{l}\text { Select Activity/List } \\
\text { Activities. }\end{array}$ & $\begin{array}{l}\text { Note: alternative step } 2 \mathrm{~b} \text { may be faster if you know the P2OA ID you want. } \\
\text { Select (hover the mouse pointer over the object and click the left mouse button once) } \\
\text { "Activity" on the main menu bar. } \\
\text { Select "List Activities" from the pulldown menu list. An "Activities" dialog box } \\
\text { appears. } \\
\text { Select the drop-down arrow, then select the appropriate activity from the list. Use the } \\
\text { vertical scroll bar to rapidly move between activities. } \\
\text { Press "OK" button to return the selection to Worksheet } 1 .\end{array}$ \\
\hline $2 b$. & $\begin{array}{l}\text { (Alternative) } \\
\text { Select Activity/Locate. }\end{array}$ & $\begin{array}{l}\text { Select "Activity" on the main menu bar. } \\
\text { Select "Locate" from the pulldown menu list. A "Locate Value" dialog box appears. } \\
\text { Enter a value to search for. (Use .. for wildcards, e.g., "222.." will find the first record } \\
\text { starting with " } 222 \text { " . } \\
\text { Select the field to search on. Hint: "Facility_ID" is the Facility. This may be a quick } \\
\text { way to find activities associated with a given facility. } \\
\text { Press "OK" button. The first instance of the associated search value will be located. } \\
\text { You may move up or down through the "stack" of existing P2OA's using the F11 and } \\
\text { F12 function keys if your keyboard supports these or use Activity/Previous } \\
\text { Activity/Next from the main menu. }\end{array}$ \\
\hline 3. & $\begin{array}{l}\text { Select Worksheet/Go } \\
\text { To Summary } \\
\text { Worksheet }\end{array}$ & $\begin{array}{l}\text { Select "Worksheet" on P2OA Worksheet l's menu bar. } \\
\text { Select "Go To Summary Worksheet" on the pulldown menu. In a moment, } \\
\text { Worksheet } 4 \text { should appear. }\end{array}$ \\
\hline 4. & $\begin{array}{l}\text { Check for proper } \mathrm{P} 2 \mathrm{O} \\
\text { Activity. }\end{array}$ & $\begin{array}{l}\text { You should now be on P2OA Worksheet } 4 \text { - Pollution Prevention Opportunity } \\
\text { Summary. Ensure the appropriate activity and facility is shown. Check the message } \\
\text { line (bottom left corner) for any messages. If the proper facility and activity does not } \\
\text { show, select "Worksheet/Go to Activities Worksheet" from the main menu bar and } \\
\text { repeat steps } 2 \text { and } 3 \text {. Alternatively, you may use similar menu selections under } \\
\text { "Activity" in the menu bar for Worksheet } 4 \text {. } \\
\text { Note: Activity, Facility, P2OA ID, Date and Facility Detail are obtained from } \\
\text { Worksheet } 1 \text {. You cannot change these fields from Worksheet } 4 \text {. }\end{array}$ \\
\hline
\end{tabular}




\begin{tabular}{|c|c|c|}
\hline \multicolumn{3}{|c|}{ Worksheet 4 - Pollution Prevention Opportunity Summary } \\
\hline & General Steps & Detail or Comment \\
\hline 5. & Check for "Edit" mode. & $\begin{array}{l}\text { If you were continuing from entry of Worksheet } 1-3 \text {, "Edit" mode should have been } \\
\text { maintained. Check the mode indicator located on the bottom line. If "Edit" is not } \\
\text { showing, you are in "View" mode. Press F9 function key (alternatively, select } \\
\text { "Activity/Edit" from the menu bar) to enter "Edit" mode. Note: you must have } \\
\text { facility specific authorization to edit. Any form may be viewed. }\end{array}$ \\
\hline 6. & $\begin{array}{l}\text { Enter "Idea Not } \\
\text { Researched.". }\end{array}$ & $\begin{array}{l}\text { Idea Not Researched is a brain stormed idea not fully researched in P2OA. } \\
\text { Select the "Idea Not Researched" entry box to type in this field. }\end{array}$ \\
\hline 7. & Enter Reason. & $\begin{array}{l}\text { Reason is the reason an idea was not researched further. } \\
\text { Select "Reason" entry box to type in this field. } \\
\text { Note: Clicking the right hand mouse button once while pointing to the "Idea Not } \\
\text { Researched" or "Reason" entry areas, an expanded editing box will appear with more } \\
\text { word processing type features available (paragraphs, indents, delete, backspace, etc.) }\end{array}$ \\
\hline 8. & $\begin{array}{l}\text { Entry Date and Entered } \\
\text { By. }\end{array}$ & $\begin{array}{l}\text { The "Entry Date" and "Entered By" are automatically filled in from the logon and } \\
\text { current date information. }\end{array}$ \\
\hline 9. & Continue, Print or Exit. & $\begin{array}{l}\text { The initial summary information for Worksheet } 4 \text { should be complete. You may } \\
\text { continue entry of worksheet } 5 \text { associated with this assessment, print a copy of } \\
\text { worksheet } 4 \text { or exit the P2SDb application. } \\
\text { To exit the application, select OK button on the worksheet (records the entered } \\
\text { information and returns to "view" mode.) Select "Exit" from the main menu bar. } \\
\text { To print the current worksheet, select "Print" from the main menu bar, then "Print } \\
\text { Worksheet" from the pulldown. You may choose to preview the report on the screen } \\
\text { first, or immediately print. See Section } 5 \text {, "Printing Worksheets" for more } \\
\text { information. Note: you must be in "View" mode to Print. If in "Edit" press F9 or } \\
\text { select Opportunity/View from the menu bar. } \\
\text { To continue entry of associated worksheets, select "Worksheet" from the main menu } \\
\text { bar. Select the worksheet you wish to work with next from the menu pulldown list. }\end{array}$ \\
\hline
\end{tabular}




\subsection{Enter a New P2OA Worksheet 5 - Final Summary}

Final summary information (includes actual results) for a particular P2OA is entered in Worksheet 5 Final Summary. Worksheet 5 must be associated with a previously entered Worksheet 1 - Team \& Activity and Worksheet 2(s)- Pollution Prevention Opportunity Description(s). It cannot be initiated first. Activity information from the associated Worksheet 1 is automatically placed on the form for you, as well as summary information from the associated opportunity worksheet(s). You cannot edit the Activity, Facility, P2OA ID or Facility Detail fields on Worksheet 5, or any of the opportunity information in the $\mathrm{P} 2 \mathrm{O}$ table. If they are in error, they must be changed on the respective Worksheet 1 or 3. There is only one Summary Worksheet available for each activity.

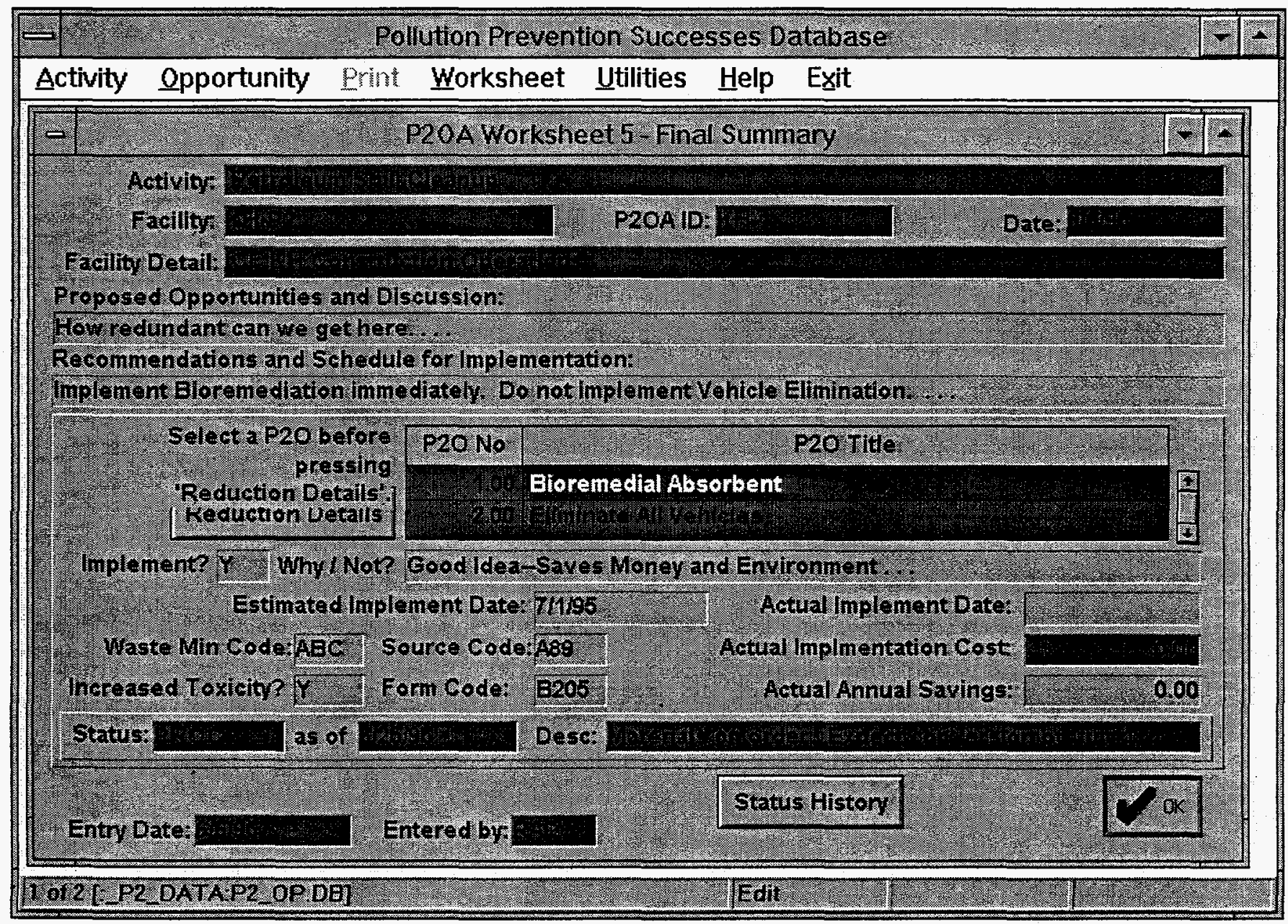

Figure 3.5 
Table 3.5

\begin{tabular}{|c|c|c|}
\hline \multicolumn{3}{|r|}{ Worksheet 5 - Final Summary } \\
\hline & General Steps & Detail or Comment \\
\hline 1. & $\begin{array}{l}\text { Start application, select } \\
\text { activity. }\end{array}$ & If not continuing from Worksheet 1 , complete steps 1 through 3 in table 3.1 above. \\
\hline 2a. & $\begin{array}{l}\text { Select Activity/List } \\
\text { Activities. }\end{array}$ & $\begin{array}{l}\text { Note: alternative step } 2 \mathrm{~b} \text { may be faster if you know the P2OA ID you want. } \\
\text { Select (hover the mouse pointer over the object and click the left mouse button once) } \\
\text { "Activity" on the main menu bar. } \\
\text { Select "List Activities" from the pulldown menu list. An "Activities" dialog box } \\
\text { appears. } \\
\text { Select the drop-down arrow, then select the appropriate activity from the list. Use the } \\
\text { vertical scroll bar to rapidly move between activities. } \\
\text { Press "OK" button to return the selection to Worksheet } 1 \text {. }\end{array}$ \\
\hline $2 \mathrm{~b}$. & $\begin{array}{l}\text { (Alternative) } \\
\text { Select Activity/Locate. }\end{array}$ & $\begin{array}{l}\text { Select "Activity" on the main menu bar. } \\
\text { Select "Locate" from the pulldown menu list. A "Locate Value" dialog box appears. } \\
\text { Enter a value to search for. (Use .. for wildcards, e.g., " } 222 \text {.." will find the first record } \\
\text { starting with "222" . } \\
\text { Select the field to search on. Hint: "Facility_ID" is the Facility. This may be a quick } \\
\text { way to find activities associated with a given facility. } \\
\text { Press "OK" button. The first instance of the associated search value will be located. } \\
\text { You may move up or down through the "stack" of existing P2OA's using the F11 and } \\
\text { F12 function keys if your keyboard supports these or use Activity/Previous } \\
\text { Activity/Next from the main menu. }\end{array}$ \\
\hline 3. & $\begin{array}{l}\text { Select Worksheet/Go } \\
\text { To Final Summary }\end{array}$ & $\begin{array}{l}\text { Select "Worksheet" on P2OA Worksheet l's menu bar. } \\
\text { Select "Go To Final Summary" on the pulldown menu. In a moment, Worksheet } 5 \\
\text { should appear. }\end{array}$ \\
\hline 4. & $\begin{array}{l}\text { Check for proper } \mathrm{P} 2 \mathrm{O} \\
\text { Activity. }\end{array}$ & $\begin{array}{l}\text { You should now be on P2OA Worksheet } 5 \text { - Final Summary (see figure 3.5). Ensure } \\
\text { the appropriate activity and facility is shown. Check the message line (bottom left } \\
\text { corner) for any messages. If the proper facility and activity does not show, select } \\
\text { "Worksheet/Go to Activities Worksheet" from the main menu bar and repeat steps } 2 \\
\text { and } 3 \text {. Alternatively, you may use similar menu selections under "Activity" in the } \\
\text { menu bar for Worksheet } 5 \text {. } \\
\text { Note: Activity, Facility, P2OA ID, Date and Facility Detail are obtained from } \\
\text { Worksheet 1. You cannot change these fields from Worksheet 5. The P2O Number } \\
\text { and Title are assigned automatically, and cannot be modified. }\end{array}$ \\
\hline
\end{tabular}




\begin{tabular}{|c|c|c|}
\hline \multicolumn{3}{|r|}{ Worksheet 5 - Final Summary } \\
\hline & General Steps & Detail or Comment \\
\hline 5. & Check for "Edit" mode. & $\begin{array}{l}\text { If you were continuing from entry of Worksheet } 1-4 \text {, "Edit" mode should have been } \\
\text { maintained. Check the mode indicator located on the bottom line. If "Edit" is not } \\
\text { showing, you are in "View" mode. Press F9 function key (alternatively, select } \\
\text { "Activity/Edit" from the menu bar) to enter "Edit" mode. Note: you must have } \\
\text { facility specific authorization to edit. Any form may be viewed. }\end{array}$ \\
\hline 6. & $\begin{array}{l}\text { Enter Proposed } \\
\text { Opportunities and } \\
\text { Discussions. }\end{array}$ & $\begin{array}{l}\text { Proposed Opportunities and Discussion is a brief overview of P2 opportunities. } \\
\text { Select the "Proposed Opportunities and Discussions" entry box to type in this field. } \\
\text { Note: Clicking the right hand mouse button once while pointing to the entry area, an } \\
\text { expanded editing box will appear with more word processing type features available } \\
\text { (paragraphs, indents, delete, backspace, etc.) }\end{array}$ \\
\hline 7. & $\begin{array}{l}\text { Enter } \\
\text { Recommendations and } \\
\text { Schedule for } \\
\text { Implementation.. }\end{array}$ & $\begin{array}{l}\text { Recommendations and Schedule for Implementation is a brief overview of } \\
\text { implementation schedule. } \\
\text { Select "Recommendations and Schedule for Implementation.." entry box to type in } \\
\text { this field. Right-click mouse for expanded editing box }\end{array}$ \\
\hline 8. & $\begin{array}{l}\text { Enter Reduction } \\
\text { Details. }\end{array}$ & $\begin{array}{l}\text { Reduction Details provide a place to record specific estimated and actual reductions, } \\
\text { annual savings and implementation costs for each waste class in the activity. } \\
\text { Select (highlight) one of the P2O Title shown in the table. A vertical scroll bar is } \\
\text { available to view all opportunities. } \\
\text { Press "Reduction Details" button or select Opportunity/Reduction Details from the } \\
\text { menu bar. A dialog box labeled "Opportunity Waste Details \& Actuals" will appear. } \\
\text { Hint(s): Use the horizontal scroll bar see all of the columns of this spreadsheet-like } \\
\text { table. Many times, you cannot see the Waste Class without scrolling } \\
\text { horizontally to the left. } \\
\text { Each of the waste class from the selected Opportunity is automatically } \\
\text { brought from the Worksheet 3, with other associated information. You } \\
\text { cannot edit this initial (base) information here, but must do it on the } \\
\text { appropriate opportunity worksheet. Actual information is added here. } \\
\text { Press "OK" when complete to return to Worksheet 5.. }\end{array}$ \\
\hline 9. & $\begin{array}{l}\text { Enter "Implement" and } \\
\text { "Why/Why Not?" }\end{array}$ & $\begin{array}{l}\text { Select "Implement" entry box and enter a Y or N. } \\
\text { Select "Why or Why Not" entry box and type in explanation. Mouse right-click for } \\
\text { an expanded editing box. }\end{array}$ \\
\hline
\end{tabular}




\begin{tabular}{|c|c|c|c|}
\hline \multicolumn{4}{|r|}{ Worksheet 5 - Final Summary } \\
\hline & General Steps & & Detail or Comment \\
\hline 10. & $\begin{array}{l}\text { Enter Estimated and } \\
\text { Actual Implementation } \\
\text { Dates.. }\end{array}$ & Press & $\begin{array}{l}\text { The appropriate entry boxes and enter dates if known. } \\
\text { There is no limit to the number of waste classes that can be entered. } \\
\text { However, they cannot be listed more than once. This is indicated by "Key } \\
\text { Violation" message appearing in the lower corner message line. Hold down } \\
\text { the Ctrl key, then press the Delete key (Ctrl-Delete) to remove the duplicate } \\
\text { waste class entry. Combine entry for one type of waste class into a single } \\
\text { line entry. } \\
\text { K" button with mouse when all components are added. }\end{array}$ \\
\hline 11. & $\begin{array}{l}\text { Enter Waste } \\
\text { Minimization, Source } \\
\text { and Form Codes. }\end{array}$ & $\begin{array}{l}\text { Select } \\
\text { in this } \\
\text { Hint: } \\
\text { Note: }\end{array}$ & $\begin{array}{l}\text { ue appropriate entry boxes and enter the codes. Lists of these codes are found } \\
\text { uide's appendixes. } \\
\text { Select (highlight) then right-click mouse on any of the code entry boxes to } \\
\text { choose from the respective authorized lists (lookup table). A value other } \\
\text { than those available on these lists will be rejected (message will appear in } \\
\text { lower left corner.) Only system administrator can modify or add to these } \\
\text { authorized values. } \\
\text { Value in the Actual Implementation Cost field is automatically calculated } \\
\text { from the reduction details. }\end{array}$ \\
\hline 12. & Enter Status History. & $\begin{array}{l}\text { Status } \\
\text { Befor } \\
\text { (highl } \\
\text { Press } \\
\text { menu } \\
\text { only a } \\
\text { table. } \\
\text { Select } \\
\text { from } \\
\text { admin } \\
\text { Select } \\
\text { editin } \\
\text { Press } \\
\text { Hint: }\end{array}$ & $\begin{array}{l}\text { listory provides a log of implementation activities for a given opportunity. } \\
\text { ressing Status History button, a specific P2O Title must be selected } \\
\text { hted) from the table. Use the vertical scroll bar if necessary. } \\
\text { Status History button, or select Opportunity/Opportunity Status from the } \\
\text { ir. A dialog box titled "P2O Status" will appear. The spreadsheet-like table is } \\
\text { iew of what has been previously entered. You cannot edit directly on this } \\
\text { New Status" entry box. Enter status code. Use mouse right-click to select } \\
\text { ist of authorized status codes. No others may be used. Only system } \\
\text { trator can modify or add to these authorized values. } \\
\text { Description or Status Details" entry box. Mouse right-click for an expanded } \\
\text { ox. } \\
\text { K" to return to Worksheet } 5 \text {. } \\
\text { If you enter this dialog box in "Edit" mode it will not let you leave by } \\
\text { pressing "OK" if "New Status" is blank or invalid. Use "Cancel" instead. }\end{array}$ \\
\hline 13 & $\begin{array}{l}\text { Entry Date and Entered } \\
\text { By fields. }\end{array}$ & $\begin{array}{l}\text { The } \\
\text { curr }\end{array}$ & $\begin{array}{l}\text { Date" and "Entered By" are automatically filled in from the logon and } \\
\text { information. }\end{array}$ \\
\hline
\end{tabular}




\begin{tabular}{|l|l|}
\hline \multicolumn{2}{|c|}{ Worksheet 5 - Final Summary } \\
\hline General Steps & \multicolumn{1}{c|}{ Detail or Comment } \\
\hline 14. Continue, Print or Exit. & $\begin{array}{l}\text { The initial summary information for Worksheet 5 should be complete. You may } \\
\text { continue entry of worksheets associated with this assessment, print a copy of the } \\
\text { worksheet 5 or exit the P2SDb application. } \\
\text { To exit the application, select OK button on the worksheet (records the entered } \\
\text { information and returns to "view" mode.) Select "Exit" from the main menu bar. } \\
\text { To print the current worksheet, select "Print" from the main menu bar, then "Print } \\
\text { Worksheet" from the pulldown. You may choose to preview the report on the screen } \\
\text { first, or immediately print. See Section 5, "Printing Worksheets" for more } \\
\text { information. Note: you must be in "View" mode to Print. If in "Edit" press F9 or } \\
\text { select Opportunity/View from the menu bar. } \\
\text { To continue entry of associated worksheets, select "Worksheet" from the main menu } \\
\text { bar. Select the worksheet you wish to work with next from the menu pulldown list. }\end{array}$ \\
\hline
\end{tabular}




\subsection{ACCESS AND EDIT AN EXISTING ASSESSMENT}

There are many reasons to access and edit an existing assessment. All of the worksheets may not have been completed, additional information has become available, or implementation status updates are available. Different from word processing documents, the information in a database may be dynamic and real time. It can also become as static as paper documents in the file cabinet if not maintained.

Editing an existing assessment is so very similar to creating a new one, it would be redundant and obtuse to provide step by step instructions. Use the steps outlined in section 3.0. The general method is given below.

- $\quad$ From the first screen (Pollution Prevention Main) menu bar, select Worksheets/P2OA Worksheets. A Team \& Activity Worksheet with information on it will appear.

- If this activity description worksheet is not the one you want, select Activity/List Activity or Activity/Locate from the menu bar. Choose an activity of interest using the steps $2 a$ or $2 b$ in Table 3.2.

- If your intent is to view or edit worksheets 2 through 5 , select Worksheet from the menu bar, then select the desired worksheet from the pulldown menu list.

- $\quad$ Follow steps 3 and 4 of Table 3.2 to get in Edit mode (press F9).

- An entire assessment may be deleted from Worksheet 1. You must be in and authorized for "Edit" mode. Select Activity/Delete from the menu bar. This function is mean-mean-mean as it deletes everything associated with the activity, including the flow worksheet, all opportunity worksheets and both final worksheets. It can ruin many hours of entry work.

Each opportunity (Worksheet 3) may be deleted. From the appropriate opportunity worksheet, select Opportunity/Opportunity Delete. 


\subsection{GENERATE ASSESSMENT REPORTS (How To Print)}

Currently, the only reports available are Paradox for Windows' individual worksheets and worksheet sets. More reports plus the current worksheets are expected to be available in WordPerfect in later phases.

The following tables provide the general steps and details for report generation.

Table 5.0

\begin{tabular}{|c|c|c|}
\hline \multicolumn{3}{|r|}{ Printing Worksheets } \\
\hline & General Steps & Detail or Comment \\
\hline 1. & $\begin{array}{l}\text { Navigate to the } \\
\text { worksheet of interest. }\end{array}$ & $\begin{array}{l}\text { Worksheets are printed by navigating to the worksheet of interest. See information in } \\
\text { Section } 4.0 \text { related to accessing worksheets. } \\
\text { Note: "View" mode is required before printing. If in "Edit" mode, press F9 to return } \\
\text { to "view." }\end{array}$ \\
\hline 2. & $\begin{array}{l}\text { Select Print/Print } \\
\text { worksheet. }\end{array}$ & $\begin{array}{l}\text { From any worksheet, select (hover the mouse pointer over the object and click the left } \\
\text { mouse button once.) Print/Print Worksheet from the menu bar. }\end{array}$ \\
\hline 3. & $\begin{array}{l}\text { Decide to print, } \\
\text { preview, export or } \\
\text { cancel report. }\end{array}$ & $\begin{array}{l}\text { "Print" sends your requested worksheet to the printer. } \\
\text { "Preview" allows you to display the report on your screen. } \\
\text { "Export" is a future function and does not operate. You will receive a "TBD" (to be } \\
\text { determined) message. } \\
\text { "Cancel" allows you to call off your particular report request. }\end{array}$ \\
\hline
\end{tabular}




\begin{tabular}{|c|c|c|c|}
\hline \multicolumn{4}{|r|}{ Printing Worksheets } \\
\hline & General Steps & & Detail or Comment \\
\hline 4. & Worksheet is printed. & $\begin{array}{l}\text { If you } \\
\text { printed } \\
\text { If you } \\
\text { maxim } \\
\text { copy ( } \\
\text { If you } \\
\text { pages, } \\
\text { When } \\
\text { dialog } \\
\text { Hints: }\end{array}$ & $\begin{array}{l}\text { lid not choose to preview the worksheet on the screen, the worksheet will be } \\
\text { immediately. } \\
\text { hose preview, a screen worksheet will be prepared. You may use the } \\
\text { ze button and scroll bars to view the entire form. If you do not want a printed } \\
\text { g., need to make some changes first) select File/Close from the menu bar. } \\
\text { re printing multiple opportunitiès (worksheet } 3 \text { 's) or a form spills to multiple } \\
\text { ou can view each page with Page on the menu bar. } \\
\text { eady to print a hard copy, select File/Print. Select OK on the "Print File" } \\
\text { ox that appears. } \\
\text { You can redirect the print to any printer your Windows has by selecting } \\
\text { File/Printer Setup before selecting File/Print. Be aware, that the report } \\
\text { generator has already created the print file for printer selected previously (or } \\
\text { the Windows default printer.) If you redirect to a different type of printer } \\
\text { (e.g., a LaserJet } 4 \text { when you originally had a LaserJet } 3 \text { selected) the resulting } \\
\text { hard copy output will look very strange. To get around this, select the printer } \\
\text { desired, then close the screen window, returning to the worksheet. Select } \\
\text { Print again, and the print file will be regenerated with the appropriate printer } \\
\text { control codes. } \\
\text { Depending on the type of printer and its location (HLAN) printing may take } \\
\text { several minutes. Once the print file has been sent to Windows Print Manager } \\
\text { (usually only } 20-30 \text { seconds) you will be returned to the worksheets where } \\
\text { you can continue to work, even if the worksheet has not completed printing. } \\
\text { Please do not use any of the other menu items shown. They can lead to the } \\
\text { internals of the application, and could cause loss of data. If this is abused, } \\
\text { the screen print feature will have to be disabled. }\end{array}$ \\
\hline
\end{tabular}


Table 5.1

\begin{tabular}{|c|c|c|}
\hline \multicolumn{3}{|r|}{ Printing P2OA Sets } \\
\hline & General Steps & Detail or Comment \\
\hline 1. & Go to Main Menu. & $\begin{array}{l}\text { If you are new to using the Pollution Prevention Successes Database (P2SDb), you } \\
\text { need to start P2SDb and log on to the system. } \\
\text { To "start," click the left mouse button twice (rapidly) while pointing to the P2SDb } \\
\text { icon. To "log on," type your Hanford ID and press Enter. Type your password and } \\
\text { select OK. }\end{array}$ \\
\hline 2. & $\begin{array}{l}\text { Select Reports/P2OA } \\
\text { Worksheet Set }\end{array}$ & $\begin{array}{l}\text { a. Select ((hover the mouse pointer over the object and click the left mouse } \\
\text { button once) "Reports" on the Main Menu bar. } \\
\text { Currently, six choices are displayed on the "Reports" pulldown. Only } \\
\text { "P2OA Worksheet Set" is functional. The remaining five are for future } \\
\text { development and are not currently functional. } \\
\text { Use Windows "printer setup" to setup your printer, not the "Printer Setup" in } \\
\text { the P2SDb "Reports" menu. } \\
\text { Caution: the "P2O Status Report" selection has been known to freeze the } \\
\text { system. Please do not test. } \\
\text { Select "P2OA Worksheet Set." The "P2OA Selection" dialog box will } \\
\text { appear. }\end{array}$ \\
\hline 3. & Choose 'All' or 'Select' & $\begin{array}{l}\text { 'All' means "All P2OAs" currently in the database. Use 'Select' when you want one } \\
\text { or more, but not necessarily all P2OA's. } \\
\text { The selections Facilities, Periods, Enterers and Searches are not functional in this } \\
\text { version. You will receive a "TBD" (to be determined) message if you select them. } \\
\text { Use 'All' go to step 3a. Go to } 3 b \text { to use 'Select.' }\end{array}$ \\
\hline 3.a & 'All' & $\begin{array}{l}\text { 1. Select 'All'. The words "All P2OAs" will display in the box on the right } \\
\text { side. } \\
\text { 2. Select 'Add' button. All P2OAs currently in the database will be added to } \\
\text { the 'Selected P2OAs' list. The expanded list may be viewed by selecting the } \\
\text { list arrow. } \\
\text { Note: There are currently more than } 200 \text { P2OAs in the database, with more } \\
\text { being added every day. Printing 'All' will result in every P2OA being } \\
\text { printed, which could be } 1000 \text { pages or more. } \\
\text { 3. Go to General Step } 4 \text {. }\end{array}$ \\
\hline
\end{tabular}




\begin{tabular}{|c|c|c|}
\hline \multicolumn{3}{|r|}{ Printing P2OA Sets } \\
\hline & General Steps & Detail or Comment \\
\hline 3.b & 'Select' & $\begin{array}{l}\text { 1. Select 'Select.' Initially, the word "none" will display in the list box on the } \\
\text { right side. } \\
\text { 2. Select the downward arrow box on the far right of the line to see a scroll list } \\
\text { of all available P2OA's. } \\
\text { 3. Select the desired P2OA. The value of your selection will overlay the } \\
\text { original word "none." } \\
\text { 4. Move your selection to the "Selected P2OAs" list by selecting the 'ADD' } \\
\text { button. The id will display. } \\
\text { If you want additional P2OA reports, repeat steps } 2 \text { through } 4 \text { inclusive. } \\
\text { When finished, go to general step } 4 .\end{array}$ \\
\hline 4. & $\begin{array}{l}\text { Clear, Remove, Cancel } \\
\text { or OK }\end{array}$ & $\begin{array}{l}\text { Cancel--will return to the P2SDb Main Menu without completing the print process. } \\
\text { Clear--will erase the selected P2OA's. This is useful if you choose to start the } \\
\text { selection process over. } \\
\text { Remove--removes the last } \mathrm{P} 2 \mathrm{OA} \text { selected. } \\
\text { OK--continues the preparation for reporting on the selected list of P2OA's. Note: if } \\
\text { you click OK with none selected, you are returned to the Main Menu. }\end{array}$ \\
\hline 5. & $\begin{array}{l}\text { Choose which } \\
\text { combination of the five } \\
\text { P2OA Worksheets you } \\
\text { want included in the } \\
\text { report. }\end{array}$ & $\begin{array}{l}\text { Worksheets } 1 \text { through } 5 \text { are listed in this "P2OA Worksheet Selection" dialog box. } \\
\text { Each of the five worksheets are marked when this dialog box first displays. If there } \\
\text { are any specific worksheets you do not want included, deselect with the mouse. } \\
\text { When you are satisfied with your combination, select the OK button. }\end{array}$ \\
\hline 6. & $\begin{array}{l}\text { Verify report type, } \\
\text { combination of } \\
\text { worksheets, and } \\
\text { criteria. }\end{array}$ & Review the "Report:" and "Criteria:" values found in the dialog box. \\
\hline 7. & $\begin{array}{l}\text { Decide to print, } \\
\text { preview, export or } \\
\text { cancel report. }\end{array}$ & $\begin{array}{l}\text { "Print" sends your requested worksheet to the printer. } \\
\text { "Preview" allows you to display the report on your screen. } \\
\text { "Export" is a future function and does not operate. You will receive a "TBD" (to be } \\
\text { determined) message. } \\
\text { "Cancel" allows you to call off your particular report request. }\end{array}$ \\
\hline
\end{tabular}




\subsection{COMMON QUESTIONS AND ANSWERS}

Q. I cannot get into Edit mode in some of the facilities I'm responsible for. What should I do?

A. The application is written with built in security to prevent others from editing assessments for facilities they shouldn't. Contact the system administrator (currently Jill Engel) to properly configure your user access privileges.

Q. The system does not have listed facilities that I'm responsible for. What should I do?

A. The application has a table of valid facilities. Contact the system administrator (currently Jill Engel) to properly configure this list.

Q. Why doesn't the DELETE key work when editing fields on the worksheets?

A. Use of the Delete [on computer keyboard] is enabled when the user is in a editing dialog box (use mouse right-click to access.) Use of the Delete [on computer keyboard] is disabled when the user is on a main worksheet as it deletes the entire field, not just one character (characteristic of the language the $P 2 S D b$ was written in.)

Q. On Worksheet 2-Flow, it is cumbersome to use the menu bar to select the different input and output entry dialog boxes. Couldn't you make a better way?

A. We have. When in edit mode, the top blank bar of each input or output box will be highlighted. Using the mouse, point to the desired box-bar and right-click. The appropriate dialog box will be retrieved.

Q. How do I enter Math Symbols?

A. Some math symbols cannot be used in calculation memo fields because of a character set constraint. We recommend using ^ (e.g. $\left.3.8^{\wedge} 10\right)$ to indicate powers.

Q. Does the application have a Spell Checker or could one be developed?

A. The native language does not have a spell checker, but we have located a third party product we hope to purchase and install in the next major release (December time frame--funds permitting.) In the interim, the application does support Microsoft Windows cross-application tools. Thus you could use Copy (Ctrl-C) and Paste (Ctrl-V) to move blocked text to and from a Windows word processor with spell check capability. This will not work with Word Perfect for DOS (version 5.1) but works well with Word Perfect for Windows or Microsoft Word. 
Q. On Worksheet 2 - Activity Flow Diagram, why do I have to calculate and key in the total number of kilograms input and total number of kilograms output? Couldn't the computer make these calculations based on the detail inputs?

A. If you enter inputs and outputs using kilogram units of measure, then P2SDb does calculate total and outputs for you. Otherwise, it cannot resolve the different units of measure.

Q. Why won't it accept my units of measure sometimes?

A. Two possibilities. First, it must be one of the authorized units of measure. The application validates your input against a list. A system administrator can edit this list.

There is also case sensitivity with respect to the entry of various values of units of measure. Thus $K G$ is an acceptable value, but $\mathrm{kg}$ and $\mathrm{Kg}$ and $k G$ are not valid values at present. If you press the right mouse button while pointing to the units, a list of valid values is displayed.

Q. Sometimes the screen seems to freeze on certain inputs, and I can't move off an entry. Any ideas?

A. One possibility is you have experienced a "key violation." This happens when the system finds you have entered a duplicate value in a key field where uniqueness is necessary to separate different records. Look at what you are entering and try to determine if there may be other items with exactly the same entry. Change your entry to obtain uniqueness.

Another possibility is one of the fields on your entry screen has a validity check that has not been met. Some fields are Required (cannot be left blank), cannot be negative, or must match validation table values maintained by system administrators. There is usually a message in the lower left corner if you try to move off (tab or mouse) a field with invalid condition.

Q. I received the message "Network Access Denied" when starting P2SDb. What should I do?

A. First, retry startup. If it again fails, contact BCSR Customer Technical Support (376-1234 or $c c:$ mail $\left.{ }^{*} C T S\right)$ and report the failure. It is not a problem with the P2SDb application.

Q. I received the message "P: drive not ready" when starting the application. What should I do?

A. This problem is usually caused by insufficient or malfunctioning network resources, and is not a problem in the P2SDb application. Substantial effort has been applied to make the application more tolerant of lost connections. Select Retry a few times from the dialog box. Many times, just waiting a minute or two and the network connection will be re-established. If this fails to work, cancel, then try a re-start. On re-start, if you receive a message "IDAPI is Busy", you must exit Windows and reboot.

Q. I receive messages about "General Protection Faults" frequently when running the application or exiting. Anything I can do? 
A. General Protection Faults or GPF's can happen for a variety of reasons. Our experience indicates the worst cause of GPF's are screen savers, particularly After Dark. If you are using anything but the Window's default screen savers, try removing them. Intermittent GPF's can also be caused by stray files in the C: $\mid$ Windows $\mid$ Temp directory. To clean this directory, exit Windows (you should have a DOS prompt like C:| $\mid>$ ). Note: do not clean the temp directory from a DOS window.

Type del c:lwindowsitemp $\left.\right|^{*} .^{*}<$ enter $>$

Answer "Yes to All"

Restart Windows by typing Win $\quad<$ enter>

Q. The performance is really poor. It can take 15 minutes to load the application, and each action takes seemingly forever. What can I do?

A. First, are you installed with a "local" configuration? See section 2.2 for more information.

Because of the size and complexity of the application, performance can be dismal on some computer configurations. Although performance is limited by network speed, it can also be improved substantially with some "tweaking" of the Windows for Workgroups parameters. Below in likely improvement order (most to least) are things that can be done.

a. The standard ESOE configuration establishes a temporary swap files. Swap files are used by Windows to swap parts of programs to disk when there is insufficient main memory to run all of the programs. The processor can access main memory in millionths of seconds, but it can take seconds to swap from disk. When you see the hourglass, and the hard disk starts making a lot of noise (thrashing) you are likely having to swap.

Windows can establish two different types of swap file, temporary and permanent. In temporary, it uses normal, slow disk file access for this swap file. In permanent, it sets up a special, contiguous swap area that it can get to much faster.

Why doesn't ESOE automatically set up a permanent swap file? Because there must be sufficient free contiguous disk space to put it, and in an automated installation, it is difficult to take into consideration every possible situation. Some users might not have sufficient disk space, which would cause the installation to fail.

To set up a permanent swap file, use the "main" group in Windows, choose Control Panel. Then choose "Enhanced". Select "virtual memory" from the dialog box, then "change". A swap area should show. Change Type to Permanent. Adjust the "new size" to something at least 20,000 KB. Anything smaller will probably cause General Protection Faults in your applications. Now start pressing dialog box "OK's" and follow instructions. This 
swap area should show. Change Type to Permanent. Adjust the "new size" to something at least 20,000 KB. Anything smaller will probably cause General Protection Faults in your applications. Now start pressing dialog box "OK's" and follow instructions. This will require a restart of Windows. If Windows cannot find sufficient contiguous disk space for a permanent swap file, it will inform you, and you will be stuck with Temporary until you can resolve.

Getting more disk space generally requires cleaning old files off the disk, then defragmenting the drive outside of Windows. This is beyond what we can address here. Find a power user to help out (almost every group has one, eh.)

b. The P2SDb application requires about 4 Mbytes of main memory (reduced from $6 \mathrm{Mb}$ in version 1.0), else it starts swapping (see above.) Any other programs you have started (cc:mail, lancal, WordPerfect, spreadsheets) also take their piece (Word Perfect for Windows, Microsoft Word and Excel all like about 4-6 Mbytes each also!) plus DOS and Windows takes about 2 Mbytes. Swapping is inevitable, but you would like to minimize it for any one program. Unfortunately, with 8 Mbyte machines, it comes quickly. Anything you can do to release memory for the application will help substantially.

The number one extra memory grabber is the smartdrive disk caching program, started before Windows in the Autoexec.bat file. Of course, disk caching is a great performance booster AFTER all applications have enough memory, and are not swapping. Its just a waste compared to letting the application get all of that millionth of a second main memory, instead of going to disk.

Smartdrive cache, by default grabs 2 Mbytes of that valuable main memory before Windows or the applications get any, on a 8 Mbyte machine. Add it up-- $2 \mathrm{MB}$ for Smartdrive, $2 M B$ for DOS+Windows, $2 M B$ for Word Perfect (dos version), .6 MB each for cc:mail, LANCAL and Phone list. Start P2SDb and it just sits and churns the disk, trying to come up with a swap combination that will give it at least $1 \mathrm{MB}$ to run in. Can't find it, but it will try for 15 minutes or more before giving up with a "General Protection Fault" error. If by chance it can get . $5 \mathrm{MB}$, it might start (in 10 minutes) but performance will be dismal as it swaps every keystroke action. Have you seen this? Now you know what is happening!

What to do? Reduce the Smartdrive size when in Windows. From Windows Program Manager, choose File (from the menu line) then Run. Enter into the box "command":

\section{SysEdit.exe}

then press $O K$.

Several stacked editing windows will show. Click on the one marked Autoexec.bat.

Find the line $>>$ \%dospth\%lSmartdrv (or something like it) 
Change to $>$ \%dospth\%lSmartdrv 20480

(adding the 20480 after Smartdrv--don't forget the spaces)

Close the Sysedit window, and answer yes to any save questions.

Leave windows, and reboot your computer (turn off, then back on.)

Your Windows applications (including P2SDb) should have $2 \mathrm{Mb}$ more to work with! Still not perfect, but lots better. Note, if you have $16 \mathrm{Mb}$ of memory, keep the cache, as the programs don't need it and it will improve disk access substantially.

c. Many users have various "wallpaper" in Windows. Wallpaper is the furthest back image in Windows. You can see it when all other images and windows are minimized. Many people have scanned images. These images must reside in main processor memory, cannot be swapped out, thus use memory that could be used by the P2SDb application (and others) to improve performance. Some of the really popular ones (e.g. Yosemete.bmp) use 750Kb (almost 1Mb) of memory! Remove this through Main/Control Panel/Desktop. 


\subsection{REPORTING PROBLEMS AND REQUESTING ENHANCEMENTS}

If there are any areas in which a User sees possible improvements in P2SDb, we welcome their suggestions and input. The User will fill out a "Software Change Request" (SCR) and Problem Report form describing the problem (see form below) and mail the completed form to Jill Engel MSIN B2-22, or MSIN E6-21 c/o "DAE". We will actively log these SCR forms. We then have P2SDb maintenance engineers resolve the SCR and implement appropriate solutions, assuming available funding.

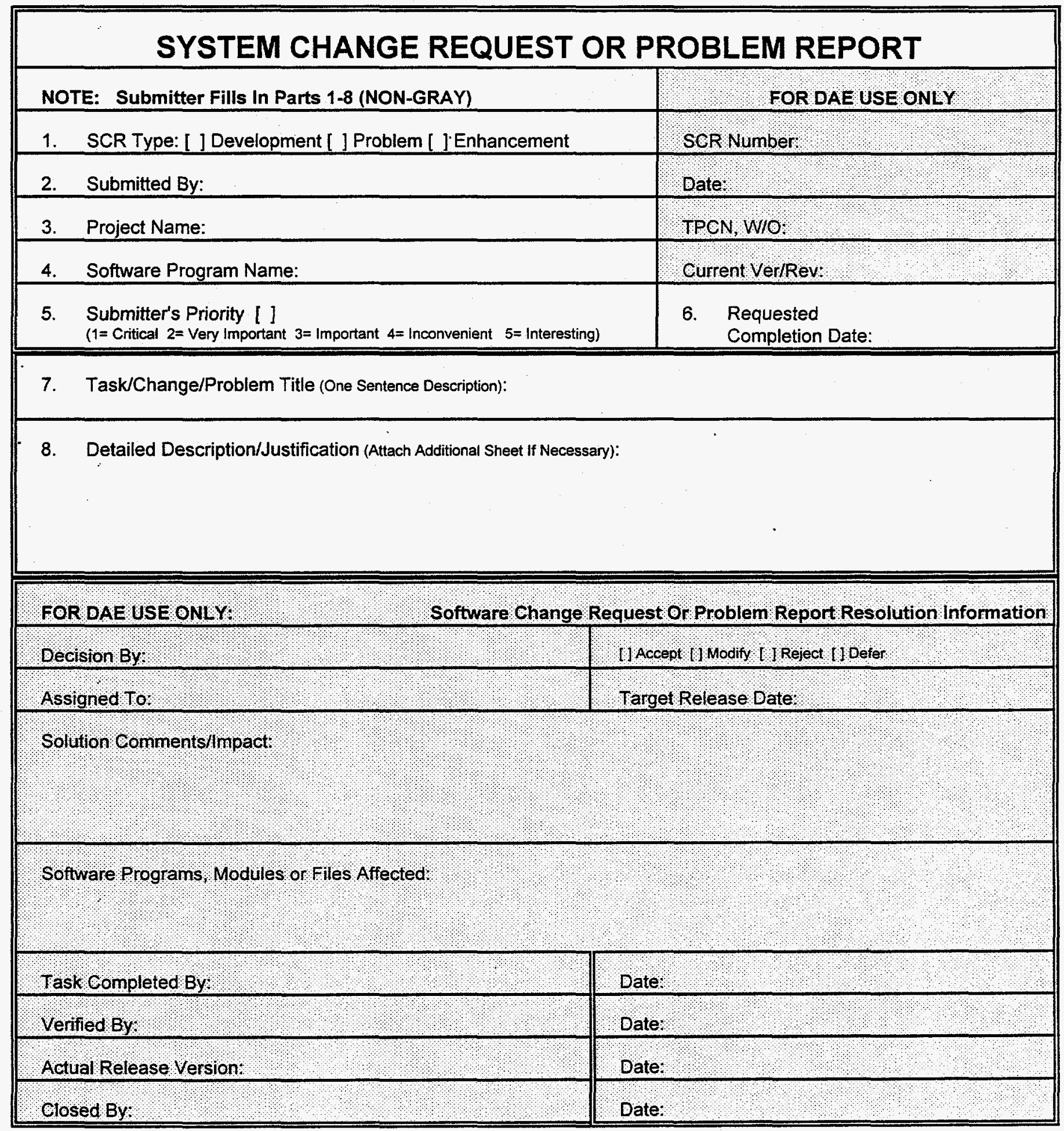


These instructions are for preparing the Change Request or Problem Report. If more space is needed, use blank pages and attach to the SCR/PR form. This will be the record of the change request or problem report.

\section{Submitter:}

1. Indicate whether this is a problem report or request for enhancement.

2. Record the name of the person submitting the form and the date.

3. Record P2SDb for project.

4. Record $\mathrm{P} 2 \mathrm{SDb}$ for software program name.

5. Record submitter's evaluated priority as shown.

6. Provide a requested completion date, or leave blank if unknown.

7. Provide a single sentence title of problem or enhancement.

8. Provide a description of the changes requested or the problems being reported. Provide justification if this is a change request. Attach additional sheets if necessary.

System Developer:

a. On receipt, enter into the SCR/PR function on the P2SDb. Enter the next SCR number on the form.

b. Enter the date received.

c. Enter TPCN or Work Order number if known, otherwise, leave blank.

d. Enter current Version/Revision of the product.

e. Review change request or problem. Mark accept, modify, reject or defer as appropriate. Project Lead Engineer signs "decision by" block, and assigns to software engineer if accepted.

f. Enter Assigned To and Target Release Date as appropriate.

g. Software Engineer fills in solution, impacts and comments area, and identifies programs, modules and files to be affected. A list may be attached.

h. Software Engineer signs "Task Completed By" block.

i. Independent reviewer signs "Verified By" block. Attach test results or additional verification documentation.

j. When included in a release, place release version in "Actual Release Version" block.

k. Project Lead Engineer signs "Closed By" block when complete or rejected. 


\section{APPENDIX A-- RESOURCES}

JA Engel, WHC Pollution Prevention $376-8737$

BCSR Customer Technical Support

376-1234

(Note--they no nothing about the application, only ESOE and HLAN)

Metric Conversion Support George Sudikatus $376-6337$ 


\section{APPENDIX B-- WASTE MINIMIZATION CODES}

Source: $\quad 1995$ Dangerous Waste Report, Washington Dept. Of Ecology, Book 2: Guidebook and Codes.

\begin{tabular}{|c|c|}
\hline Waste Min Code & Waste Minimization Code Description \\
\hline W01 & RECYCLING-On-site recycling began during 1995. \\
\hline W02 & RECYCLING-Off-site recycling began during 1995. \\
\hline W11 & $\begin{array}{l}\text { SOURCE REDUCTION-Began to segregate types of hazardous waste to make them more amenable to } \\
\text { recycling. }\end{array}$ \\
\hline W12 & $\begin{array}{l}\text { SOURCE REDUCTION-Began to segregate (stopped combining) hazardous waste from non-hazardous } \\
\text { waste. }\end{array}$ \\
\hline W13 & SOURCE REDUCTION-Improved maintenance scheduling, recordkeeping, or procedures. \\
\hline W14 & $\begin{array}{l}\text { SOURCE REDUCTION-Changed production schedule to minimize equipment and feedstock } \\
\text { changeovers. }\end{array}$ \\
\hline W19 & SOURCE REDUCTION-Other Changes in operating practices (Specify in Comments). \\
\hline W21 & $\begin{array}{l}\text { SOURCE REDUCTION-Instituted procedures to ensure materials don't stay in inventory beyond shelf- } \\
\text { life. }\end{array}$ \\
\hline W22 & SOURCE REDUCTION-Began to test outdated material-continue to use if still effective. \\
\hline W23 & SOURCE REDUCTION-Eliminated shelf-life requirements for stable materials. \\
\hline W24 & SOURCE REDUCTION-Instituted better labeling procedures. \\
\hline W25 & $\begin{array}{l}\text { SOURCE REDUCTION-Instituted clearinghouse to exchange materials that would otherwise be } \\
\text { discarded. }\end{array}$ \\
\hline W29 & SOURCE REDUCTION-Other Inventory Control (Specify in Comments). \\
\hline W31 & SOURCE REDUCTION-Improved storage or stacking procedures. \\
\hline W32 & SOURCE REDUCTION-Improved procedures for loading, unloading, and transfer operations. \\
\hline W33 & SOURCE REDUCTION-Installed overflow alarms or automatic or automatic shut-off valves. \\
\hline W34 & SOURCE REDUCTION-Installed secondary containment. \\
\hline W35 & SOURCE REDUCTION-Installed vapor recovery systems. \\
\hline W36 & $\begin{array}{l}\text { SOURCE REDUCTION-Implemented inspection or monitoring program of potential spill or leak } \\
\text { sources. }\end{array}$ \\
\hline W39 & SOURCE REDUCTION- Other Spill and Leak Prevention (Specify in Comments). \\
\hline W41 & SOURCE REDUCTION-Increased purity of raw materials. \\
\hline W42 & SOURCE REDUCTION-Substituted raw materials. \\
\hline W49 & SOURCE REDUCTION-Other Raw Material Modifications (Specify in Comments). \\
\hline W51 & SOURCE REDUCTION-Instituted closed-loop recycling. \\
\hline W52 & SOURCE REDUCTION-Modified equipment, layout, or piping. \\
\hline
\end{tabular}




\begin{tabular}{|c|c|}
\hline Waste Min Code & Waste Minimization Code Description \\
\hline W53 & SOURCE REDUCTION-Changed process catalyst \\
\hline W54 & SOURCE REDUCTION-Instituted better controls on operating conditions (flow rate, temp., pressure). \\
\hline W55 & $\begin{array}{l}\text { SOURCE REDUCTION-Change from small volume to bulk containers to minimize discard of empty } \\
\text { containers. }\end{array}$ \\
\hline W58 & SOURCE REDUCTION-Other Process Modifications (Specify in Comments). \\
\hline W59 & SOURCE REDUCTION-Modified stripping/cleaning equipment. \\
\hline W60 & $\begin{array}{l}\text { SOURCE REDUCTION-Changed to mechanical stripping/cleaning devices (from solvents or other } \\
\text { material). }\end{array}$ \\
\hline W61 & SOURCE REDUCTION-Changed to aqueous cleaners )from solvents or other materials). \\
\hline W63 & SOURCE REDUCTION-Modified containment procedures for cleaning units. \\
\hline W64 & SOURCE REDUCTION-Improved draining procedures. \\
\hline W65 & SOURCE REDUCTION-Redesigned parts racks to reduce dragout. \\
\hline W66 & SOURCE REDUCTION-Modified or installed rinse systems. \\
\hline W67 & SOURCE REDUCTION-Improved rinse equipment design. \\
\hline W68 & SOURCE REDUCTION-Improved rinse equipment operation. \\
\hline W71 & SOURCE REDUCTION-Other Cleaning and Degreasing (Specify in Comments). \\
\hline W72 & SOURCE REDUCTION-Modified spray systems or equipment. \\
\hline W73 & SOURCE REDUCTION-Substituted coating materials used. \\
\hline W74 & SOURCE REDUCTION-Improved application techniques. \\
\hline W75 & SOURCE REDUCTION-Changed from spray to other system. \\
\hline W78 & SOURCE REDUCTION- Other Surface Preparation and Finishing (Specify in Comments). \\
\hline W81 & SOURCE REDUCTION-Changed product specifications. \\
\hline W82 & SOURCE REDUCTION-Modified design or composition. \\
\hline W83 & SOURCE REDUCTION-Modified packaging \\
\hline W89 & SOURCE REDUCTION-Other Product Modifications (Specify in Comments). \\
\hline W99 & SOURCE REDUCTION-Other Source Reduction Activity (Specify in Comments). \\
\hline
\end{tabular}




\section{APPENDIX C-- SOURCE CODE DESCRIPTIONS}

Source: $\quad 1995$ Dangerous Waste Report, Washington Dept. Of Ecology, Book 2: Guidebook and Codes.

\begin{tabular}{|c|c|}
\hline Source Code & Source Description \\
\hline $\mathrm{AOl}$ & Cleaning and Degreasing - Stripping. \\
\hline $\mathrm{A02}$ & Cleaning and Degreasing - Acid cleaning. \\
\hline $\mathrm{A03}$ & Cleaning and Degreasing - Caustic (Alkali) cleaning. \\
\hline $\mathrm{A04}$ & Cleaning and Degreasing - Flush rinsing. \\
\hline A05 & Cleaning and Degreasing - Dip rinsing. \\
\hline A06 & Cleaning and Degreasing - Spray rinsing. \\
\hline A07 & Cleaning and Degreasing - Vapor degreasing. \\
\hline :08 & Cleaning and Degreasing - Physical scraping and removal. \\
\hline A09 & Cleaning and Degreasing - Other cleaning and degreasing. \\
\hline A21 & Surface Preparation and Finishing - Painting. \\
\hline A22 & Surface Preparation and Finishing - Electroplating. \\
\hline A23 & Surface Preparation and Finishing - Electroless plating. \\
\hline A24 & Surface Preparation and Finishing - Phosphating. \\
\hline A25 & Surface Preparation and Finishing - Heat treating. \\
\hline A26 & Surface Preparation and Finishing - Pickling. \\
\hline A27 & Surface Preparation and Finishing - Etching. \\
\hline A29 & Surface Preparation and Finishing - Other surface coating/preparation. \\
\hline A31 & Processes Other Than Surface Preparation - Product rinsing. \\
\hline A33 & Processes Other Than Surface Preparation - Product distillation. \\
\hline A34 & Processes Other Than Surface Preparation - Product solvent extraction. \\
\hline A35 & Processes Other Than Surface Preparation - By-product processing. \\
\hline A36 & Processes Other Than Surface Preparation - Spent catalyst removal. \\
\hline A37 & Processes Other Than Surface Preparation - Spent process liquids removal. \\
\hline A38 & Processes Other Than Surface Preparation - Tank sludge removal. \\
\hline A39 & Processes Other Than Surface Preparation - Slag removal. \\
\hline A40 & Processes Other Than Surface Preparation - Metal forming. \\
\hline A41 & Processes Other Than Surface Preparation - Plastics forming. \\
\hline A49 & Processes Other Than Surface Preparation - Other processes other than surface prep. \\
\hline A51 & Production/Service Derived 1Time \& Intermit.Processes-Leak collection. \\
\hline
\end{tabular}




\begin{tabular}{|c|c|}
\hline Source Code & Source Description \\
\hline A53 & Production/Service Derived 1Time \& Inermit.Processes-Cleanup of spill residues. \\
\hline A54 & Production/Service Derived 1Time \& Intermit.Processes-Oil changes. \\
\hline A55 & Production/Service Derived 1Time \& Intermit.Processes-Filter/Battery replacement. \\
\hline A56 & Production/Service Derived 1Time \& Intermit.Processes-Discontinue use process equipment. \\
\hline A57 & Production/Service Derived 1 Time \& Inermit.Processes-Discarding off-spec material. \\
\hline A58 & Production/Service Derived 1Time \& Intermit.Processes-Discard out-dated products/chem. \\
\hline A59 & Production/Service Derived 1 Time \& Intermit.Processes-Other prod.-derived $1 x \&$ i.proc. \\
\hline A60 & Production/Service Derived 1 Time \& Intermit.Processes-Sludge removal. \\
\hline A61 & Remediation Derived Waste-Superfund Remedial Action. \\
\hline A62 & Remediation Derived Waste-Superfund Emergency Response. \\
\hline A63 & Remediation Derived Waste-RCRA Corrective Action at solid waste mgmt. unit \\
\hline A64 & Remediation Derived Waste-RCRA closure of hazardous waste mgmt. unit. \\
\hline A65 & Remediation Derived Waste-Underground storage tank cleanup. \\
\hline A69 & Remediation Derived Waste-Other remediation. \\
\hline A71 & Pollution Control/Waste Treatment Processes-Filtering/screening. \\
\hline A72 & Pollution Control/Waste Treatment Processes-Metals recovery. \\
\hline A73 & Pollution Control/Waste Treatment Process-solvents recovery. \\
\hline A74 & Pollution Control/Waste Treatment Processes-Incineration/Thermal treatment. \\
\hline A75 & Pollution Control/Waste Treatment Processes-Wastewater treatment. \\
\hline A76 & Pollution Control/Waste Treatment Processes-Sludge dewatering. \\
\hline A77 & Pollution Control/Waste Treatment Processes-Stabilization. \\
\hline A78 & Pollution Control/Waste Treatment Processes-Air pollution control devices. \\
\hline A79 & Pollution Control/Waste Treatment Processes-Leachate collection. \\
\hline A89 & Pollution Control/Waste Treatment Processes-Other pollution control/waste treatment. \\
\hline A91 & Other Processes-Clothing and personal protective equipment. \\
\hline A92 & Other Processes-Routine cleanup wastes (e.g., floor sweeping). \\
\hline A93 & Other Processes-Closure of mgmt. units/equipment other than by remed. in codes A61, A69. \\
\hline A94 & Other Processes-Laboratory wastes. \\
\hline A99 & Other Processes-Other. \\
\hline
\end{tabular}




\section{APPENDIX D-- FORM CODE DESCRIPTIONS}

Source: 1995 Dangerous Waste Report, Washington Dept. Of Ecology, Book 2: Guidebook and Codes.

\begin{tabular}{|c|c|}
\hline Form Code & Form Description \\
\hline B009 & LAB PACKS - lab packs. \\
\hline B101 & INORGANIC LIQUIDS - Aqueous waste with low solvents. \\
\hline $\mathrm{B} 102$ & INORGANIC LIQUIDS - Aqueous waste with low other toxic organics. \\
\hline $\mathrm{B} 103$ & INORGANIC LIQUIDS - Spent acid with metals. \\
\hline B104 & INORGANIC LIQUIDS - Spent acid without metals. \\
\hline $\mathrm{B} 105$ & INORGANIC LIQUIDS - Acidic aqueous waste. \\
\hline B106 & INORGANIC LIQUIDS - Caustic solution with metals but no cyanides. \\
\hline B107 & INORGANIC LIQUIDS - Caustic solution with metals and cyanides. \\
\hline B108 & INORGANIC LIQUIDS - Caustic solution with cyanides but no metals. \\
\hline B109 & INORGANIC LIQUIDS - Spent caustic. \\
\hline B110 & INORGANIC LIQUIDS - Caustic aqueous waste. \\
\hline B111 & INORGANIC LIQUIDS p Aqueous waste with reactive sulfides. \\
\hline B112 & INORGANIC LIQUIDS - Aqueous waste with other reactives (e.g., explosives). \\
\hline B113 & INORGANIC LIQUIDS - Other aqueous waste with high dissolved solids. \\
\hline B114 & INORGANIC LIQUIDS - Other aqueous waste with low dissolved solids. \\
\hline B115 & INORGANIC LIQUIDS - Scrubber water \\
\hline B1116 & INORGANIC LIQUIDS - Leachate. \\
\hline B117 & INORGANIC LIQUIDS - Waste liquid mercury. \\
\hline B119 & INORGANIC LIQUIDS - Other Inorganic liquids (Specify in Comments). \\
\hline B201 & ORGANIC LIQUIDS - Concentrated solvent water solution. \\
\hline B202 & ORGANIC LIQUIDS - Halogenated (e.g., chlorinated) solvent. \\
\hline B203 & ORGANIC LIQUIDS - Nonhalogenated solvent. \\
\hline B204 & ORGANIC LIQUIDS - Halogenated/nonhalogenated solvent mixture. \\
\hline B205 & ORGANIC LIQUIDS - Oil-water emulsion or mixture. \\
\hline B206 & ORGANIC LIQUIDS - Waste oil. \\
\hline B207 & ORGANIC LIQUIDS - Concentrated aqueous solution of other organics. \\
\hline B208 & ORGANIC LIQUIDS - Concentrated phenolics. \\
\hline B209 & ORGANIC LIQUIDS - Organic paint, ink, lacquer, or varnish. \\
\hline B210 & ORGANIC LIQUIDS - Adhesives or epoxies. \\
\hline
\end{tabular}




\begin{tabular}{|c|c|}
\hline Form Code & Form Description \\
\hline B211 & ORGANIC LIQUIDS - Paint Thinner or petroleum distillates. \\
\hline $\mathrm{B} 212$ & ORGANIC LIQUIDS - Reactive or polymerizable organic liquid. \\
\hline B219 & ORGANIC LIQUIDS - Other organic liquids (Specify in Comments). \\
\hline $\mathrm{B} 301$ & INORGANIC SOLIDS - Soil contaminated with organics. \\
\hline $\mathrm{B} 302$ & INORGANIC SOLIDS - Soil contaminated with inorganics only. \\
\hline B303 & INORGANIC SOLIDS - Ash, slag, or other residue from incineration of wastes. \\
\hline B304 & INORGANIC SOLIDS - Other "dry" ash, slag, or thermal residue. \\
\hline B305 & INORGANIC SOLIDS - "Dry" lime or metal hydroxide solids chemically "fixed". \\
\hline B306 & INORGANIC SOLIDS - "Dry" lime or metal hydroxide solids not "fixed". \\
\hline B307 & INORGANIC SOLIDS - Metal scale, filings, or scrap. \\
\hline B308 & INORGANIC SOLIDS - Empty or crushed metal drums or containers. \\
\hline B309 & INORGANIC SOLIDS - Batteries or battery parts, casings, cores. \\
\hline B310 & INORGANIC SOLIDS - Spent solid filters or adsorbents. \\
\hline B311 & INORGANIC SOLIDS - Asbestos solids and debris. \\
\hline B312 & INORGANIC SOLIDS - Metal-cyanide salts/chemicals. \\
\hline B313 & INORGANIC SOLIDS - Reactive cyanide salts/chemicals/ \\
\hline B314 & INORGANIC SOLIDS - Reactive sulfide salts/chemicals. \\
\hline B315 & INORGANIC SOLIDS - Other reactive salts/chemicals. \\
\hline B316 & INORGANIC SOLIDS - Other metal salts/chemicals. \\
\hline B319 & INORGANIC SOLIDS - Other waste inorganic solids (Specify in Comments). \\
\hline B401 & ORGANIC SOLIDS - Halogenated pesticide solid. \\
\hline B402 & ORGANIC SOLIDS - Nonhalogenated pesticide solid. \\
\hline B403 & ORGANIC SOLIDS - solid resins or polymerized organics. \\
\hline B404 & ORGANIC SOLIDS - Spent carbon. \\
\hline B405 & ORGANIC SOLIDS - Reactive organic solid. \\
\hline B406 & ORGANIC SOLIDS p Empty fiber or plastic containers. \\
\hline B407 & ORGANIC SOLIDS - Other halogenated organic solids (Specify in Comments). \\
\hline B409 & ORGANIC SOLIDS - Other nonhalogenated organic solids (Specify in Comments). \\
\hline B501 & INORGANIC SLUDGES-Lime sludge without metal. \\
\hline B502 & INORGANIC SLUDGES - Lime sludge with metals/metal hydroxide sludge. \\
\hline B503 & INORGANIC SLUDGES - Wastewater treatment sludge with toxic organics. \\
\hline
\end{tabular}




\begin{tabular}{|c|c|}
\hline Form Code & Form Description \\
\hline B504 & INORGANIC SLUDGES-Other wastewater treatment sludges. \\
\hline B505 & INORGANIC SLUDGES - Untreated plating sludge without cyanides. \\
\hline B506 & INORGANIC SLUDGES - Untreated plating sludge with cyanides. \\
\hline B507 & INORGANIC SLUDGES - Other sludge with cyanides. \\
\hline B508 & INORGANIC SLUDGES - Sludge with reactive sulfides. \\
\hline B509 & INORGANIC SLUDGES - Sludge with other reactives. \\
\hline B510 & INORGANIC SLUDGES - Degreasing sludge with metal scale or filings. \\
\hline B511 & INORGANIC SLUDGES - Air pollution control device sludge (e.g., fly ash). \\
\hline B512 & INORGANIC SLUDGES - Sediment or lagoon dragout contaminated with organics. \\
\hline B513 & INORGANIC SLUDGES - Sediment or lagoon dragout contaminated with inorganics only. \\
\hline B514 & INORGANIC SLUDGES - Drilling mud. \\
\hline B515 & INORGANIC SLUDGES - Asbestos slurry or sludge. \\
\hline B516 & INORGANIC SLUDGES - Chloride or other brine sludge. \\
\hline B519 & INORGANIC SLUDGES O Other inorganic sludges (Specify in Comments). \\
\hline B601 & ORGANIC SLUDGES - Still bottoms of halogenated (e.g., chlorinated) solvents or other. \\
\hline $\mathrm{B} 602$ & ORGANIC SLUDGES - Still bottoms of nonhalogenated solvents or other organic liquids. \\
\hline $\mathrm{B} 603$ & ORGANIC SLUDGES - Oily sludge. \\
\hline B604 & ORGANIC SLUDGES - Organic paint or ink sludge. \\
\hline B605 & ORGANIC SLUDGES - Reactive or polymerizable organics. \\
\hline B606 & ORGANIC SLUDGES - Resins, tars, or tarry sludge. \\
\hline B607 & ORGANIC SLUDGES - Biological treatment sludge. \\
\hline B608 & ORGANIC SLUDGES - Sewage or other untreated biological sludge. \\
\hline B609 & ORGANIC SLUDGES - Other organic sludges (Specify in Comments) \\
\hline B701 & INORGANIC GASES \\
\hline B801 & ORGANIC GASES \\
\hline
\end{tabular}




\section{APPENDIX E: ACRONYMS AND GLOSSARY}

ACRONYM EXPANDED DESCRIPTION

1. P2 Pollution Prevention

2. $\mathrm{P} 2 \mathrm{OA}$ Pollution Prevention Opportunity Assessment

3. P2SDb Pollution Prevention Successes Database

4. SWITS Solid Waste Information Tracking System 